\title{
Outdoor Urban Nanomaterials: The Emergence of a New, Integrated, and Critical Field of Study
}

Mohammed Baalousha ${ }^{1 *}$, Yi Yang ${ }^{2,3^{*}}$, Marina E. Vance ${ }^{4}$, Ben Coleman ${ }^{5}$, Samantha McNeal ${ }^{1}$, Jie $\mathrm{Xu}^{3}$, Joanna Blaszczak ${ }^{5}$, Meredith Steele ${ }^{6}$, Emily Bernhardt ${ }^{5}$, Michael F. Hochella, $\mathrm{Jr}^{3,7}$

${ }^{1}$ Center for Environmental Nanoscience and Risk, Department of Environmental Health Sciences, University of South Carolina, Columbia, SC 29208, USA

${ }^{2}$ Department of Geosciences, East China Normal University, 3663 North Zhongshan Road, Shanghai, 200062, China ${ }^{3}$ Center for NanoBioEarth, Department of Geosciences, Virginia Tech, Blacksburg, VA 24061-0420, USA

${ }^{4}$ Institute for Critical Technology and Applied Science, 410 Kelly Hall, Virginia Tech, Blacksburg, VA 24061-0420, USA

${ }^{5}$ Biology Department, Duke University, Durham, NC, 27708, USA

${ }^{6}$ College of Agriculture and Life Sciences, Virginia Tech, Blacksburg, VA 24061-0420, USA

${ }^{7}$ Geosciences Group, Pacific Northwest National Laboratory, Richland, WA 99354, USA

*Corresponding authors: yyang@geo.ecnu.edu.cn; mbaalous@mailbox.sc.edu 


\begin{abstract}
Engineered nanomaterials (ENMs) are currently widely incorporated in the outdoor urban environmental fabric and numerous new applications and products containing ENMs are expected in the future. As has been shown repeatedly, products containing ENMs have the potential, at some point in their lifetime, to release ENMs into their surrounding environment. However, the expanding body in environmental nanomaterial research has not yet shifted towards ENMs in the context of the complex outdoor urban environment. This is especially surprising because the world's human populations are on a steady march toward more and more urbanization and technological development, accompanied with increased applications for ENMs in the outdoor urban environment. Our objective for this paper is therefore to review, assess, and provide new information in this emerging field. We provide an overview of nanomaterials (NMs, encompassing both ENMs and incidental nanomaterials, INMs) that are likely to be released in the urban environment from outdoor sources by discussing 1) the applications of ENMs that may lead to release of ENMs in urban areas, 2) the recently published data on the release of ENMs from novel nano-enabled applications in the outdoor urban environment, 3 ) the available literature on the occurrence of INMs in the atmosphere and within/on dust particles, and 4) the potential pathways and fate of NMs in the outdoor urban environment. This review is then followed by three case studies demonstrating the importance of NMs in the outdoor urban environment. The first and second case studies illustrate the occurrence of NMs in urban dust and stormwater ponds, respectively, whereas the third case study discusses the lessons learned from the release of $\mathrm{NMs}$ (e.g. $\mathrm{Pt}, \mathrm{Ph}$ and $\mathrm{Rh}$ ) from automotive vehicle catalytic convertors. This article ends with a discussion of the research priorities needed to advance this emerging field of "outdoor urban nanomaterials" and to assess the potential risks of NMs in the context of urban environments.
\end{abstract}

\title{
Graphical Abstract
}




\section{Introduction}

Today, $54 \%$ of the world's population lives in urban areas, and is expected to increase to $66 \%$ by 2050 (United Nations, 2014). The presence of such concentrated populations has profound impacts on the environment (Lyons and Harmon, 2012) such as decreased green space, increased impervious cover, increased traffic density, and increased human activities in confined areas. Therefore, urbanization results in increased emissions of pollutants within more densely populated areas, increased pollutant deposition (wet/dry) on impervious cover, reduced stormwater infiltration, increased surface runoff, etc. Stormwater carries contaminants deposited on impervious surfaces to adjacent surface waters (Tixier et al., 2011; Wong et al., 2006). Thus, urbanization results in an enhanced transport of significant quantities of contaminants (e.g. metallic and organic) to nearby surface waters resulting in deterioration of water quality and increased threats to environmental and human health (Ancion et al., 2010). The term "urban geochemistry" was coined by Thornton in 1990 to describe "the interface of environmental geochemistry and urban pollution", which has become an important scientific discipline and portrayed as a current "frontier" scientific area (Jartun and Ottesen, 2011; Lyons and Harmon, 2012; Wong et al., 2006). So far, little attention has been given to emerging contaminants such as engineered nanomaterials and their potential role as a vector for other contaminants (Yan et al., 2015). ENMs are generally defined as materials with at least one dimension in the size range of 1-100 nm (Christian et al., 2008; Klaine et al., 2008). Nonetheless, different governmental and international agencies have more specific definitions that we have summarized and reviewed elsewhere (Baalousha et al., 2014).

As a major product of the nanotechnology industry, ENMs are widely used in the context of the outdoor urban environment. Examples include ENMs used in conjunction with self-cleaning surfaces, paint and other coatings, and other applications and are summarized below (Munafò et al., 2014; Pazokifard et al., 2013). ENMs can be released from nano-enabled products and applications in the outdoor urban environment and find their way to the surrounding environment. For instance, recent studies have provided evidence that leached Ag-ENMs and $\mathrm{TiO}_{2}-$ ENMs from exterior façades and $\mathrm{TiO}_{2}$-ENM in sunscreens may be important inputs of $\mathrm{Ag}$ and $\mathrm{TiO}_{2}$-ENMs into streams (Gondikas et al., 2014; Kaegi et al., 2008; Kaegi et al., 2010).

So far, significant attention has been given to characterize the occurrence and transformations of ENMs in waste water treatment plants (WWTPs), as they are predicted to be one of the major conveyances of ENMs to the environment (Gottschalk et al., 2009; Gottschalk et al., 2013). However, little attention has been given to the occurrence and transformations of ENMs and incidental nanomaterials (INMs; those nanomaterials unintentionally generated as a 
side product of anthropogenic processes) in urban runoff. In terms of the urban atmospheric environment, INM emissions from vehicular sources have been studied extensively and are often regulated (Kumar et al., 2014), but the potential presence of airborne ENMs in outdoor urban environments has gained little attention. Given the current knowledge gap regarding NMs (ENMs and INMs) in the outdoor urban environment, this article aims to provide an overview of the potential occurrence, transport and transformations of NMs in the outdoor urban environment by critically reviewing: 1) the applications of ENMs in the context of the outdoor urban environment, 2) the recently published data on release of ENMs from novel nano-enabled applications in the outdoor urban environment, 3) the available literature on the occurrence of INMs in atmospheric and dust particles, 4) the potential transformations and pathways of NMs in the outdoor urban environment, and lastly 5) the research priorities to advance this emerging field of study to assess potential risks of NMs in the urban environment. In addition to the literature review, the article also presents three case studies to demonstrate the occurrence of numerous types of $\mathrm{NMs}$ (e.g., $\mathrm{FeO}_{\mathrm{x}}, \mathrm{TiO}_{2}, \mathrm{ZnO}, \mathrm{CePO}_{4}, \mathrm{ZrSiO}_{4}$, and others) in the urban environment (i.e., atmospheric particles, water and sediments from stormwater ponds, and surface waters). This article also reviews studies on both ENMs and INMs due to the challenges in differentiating between these two types of NMs found in the environment using current stateof-the-art methods.

\section{Applications of ENMs in the urban environment}

Nanotechnology is a rapidly growing innovative technology that exploits the novel properties of ENMs to develop new products and enhance the performance of existing products (Baalousha et al., 2014; Christian et al., 2008). "Urban nanotechnologies are products, structures, and processes using ENMs that are embedded in the "urban fabric", that is the dynamic, spatially-agglomerated complex of activities, buildings, infrastructures, technical devices, ecosystems that comprise the contemporary metropolis (Wiek et al., 2013)" and are currently growing rapidly. In the outdoor urban environment, ENMs can be found in a wide range of applications (Table S1) such as scratch resistant surface coatings, fuel additives to enhance fuel efficiency, superior paints, hydrophobic surfaces to repel water and dirt, wood coatings to prevent discoloration, self-cleaning surfaces, photocatalytic concrete pavements, photovoltaic materials covering building surfaces to harness sunlight and locally generate electricity, moisture adsorbents, high-performance tires, antireflection layers for road signs and panels, better road markings, and improving incineration processes (Adachi, 2006; Dylla and 
Hassan, 2012; Lee et al., 2010; OECD., 2014; Ugwu, 2013; van Broekhuizen and van Broekhuizen, 2009; van Broekhuizen et al., 2011; Wiek et al., 2013; Yu et al., 2012)..

One particular example of significant importance for environmental release of ENMs in the context of the outdoor urban environment is the growing use of ENMs for self-cleaning glass and building façade painting in the urban environment. The worldwide coatings market is expected to reach $\$ 107$ billion by 2017 (Global Industry Analysts Coatings, 2012). The unique properties of ENMs (Table S1) make them of significant interest for developing new paint and coating formulations capable of satisfying many conditions and application requirements, e.g., preventing microbial growth on surfaces, erosion and abrasion resistance, preventing paint degradation by UV light, etc. Major factors driving growth in the self-cleaning coating market include rapid industrialization of new economies and increasing demand for end-use sectors, e.g. the automotive and construction sectors. For instance, eight million square meters of façades treated with biocidal coatings are built in Switzerland every year (Künniger et al., 2014). Self-cleaning glass, used for example on the roof structure of St Pancras Station in London (covering $10,000 \mathrm{~m}^{2}$ and using 18,000 panels of self-cleaning glass), is covered by a $\mathrm{TiO}_{2} \mathrm{ENM}$ catalyst which breaks down deposited atmospheric particles in the presence of sunlight (Winkless, 2013). $\mathrm{TiO}_{2}$ ENM coating the self-cleaning windows can then be released slowly overtime due to coating weathering (see discussion below).

The Wilson Center's inventory of consumer products enhanced with ENMs lists 355 products in the "Home and Garden" category, which includes paints and other construction materials (Vance et al., 2015). Currently, it is estimated that $10-30 \%$ of $\mathrm{TiO}_{2}, 30 \%$ of $\mathrm{ZnO}$, 5$10 \%$ of $\mathrm{CeO}_{2}$ and $10-30 \%$ of $\mathrm{Ag}$ ENMs produced worldwide are used in paint and coatings (Piccinno et al., 2012). Even traditional pigments (e.g. $\mathrm{TiO}_{2}$ ) contain a nanosized fraction; 36\% of particles are below $100 \mathrm{~nm}$ (Weir et al., 2012), that is NMs according to widely accepted NM definition. This is because the large majority of commercially produced particles are highly polydispersed (Baalousha and Lead, 2013). The release of ENMs from these outdoor urban nanotechnologies represents both a direct and diffuse pathway into the environment.

\section{Release of ENMs from nano-enabled applications in the urban environment}

As with any other technology, outdoor urban nanotechnologies are likely to create pollution and waste streams due to the degradation and erosion of nano-enabled products. These nanowaste streams may further aggravate pre-existing urban stressors (Wiek et al., 2013). 
Nevertheless, nano-enabled products may also replace other toxic substances commonly used in the urban environment in façade coatings and paints (U.S.EPA., 2011), and thus a benefitrisk balanced approach should be adopted in evaluating the use of ENMs in the urban environment.

Large-scale, nano-enabled surfaces of urban buildings and other infrastructures are exposed to wind, rain, ice, and other variable weather conditions, thus triggering ENM erosion that can lead to air/water transport and deposition of these ENMs into/onto soil, surface water, and impervious surfaces (Künniger et al., 2014). ENMs used in fabrics (e.g. ropes, sails, tents, traps) can be washed away with rainwater, as Ag ENMs are released from fabrics when washed (Benn and Westerhoff, 2008). ENMs used in paint (e.g., Ag and $\mathrm{TiO}_{2}$ ) have also been shown to be released into urban runoff in simulated rainy weather conditions (Kaegi et al., 2008; Kaegi et al., 2010).

Several studies have focused on the release of ENMs $\left(\mathrm{TiO}_{2}, \mathrm{Ag}\right.$ and $\left.\mathrm{SiO}_{2}\right)$ from photocatalytic surfaces and paint under simulated/field rainwater conditions (Table S2), and are thus reviewed here in detail as an example of one of the major applications of ENMs in the outdoor urban environment. These studies suggest that the use of photocatalytic coatings with surface-bound ENMs may entail new entries of ENMs into the environment (atmosphere, soil and surface waters; Künniger et al., 2014). Among the first studies on the release of ENMs from paint to urban runoff and surface waters, Kaegi et al. $(2008,2010)$ reported a release of ca. 10 $\mathrm{mg} \mathrm{m}^{-2}$ of $\mathrm{Ti}$ (equivalent to $16.7 \mathrm{mg} \mathrm{m}^{-2} \mathrm{TiO}_{2}$ ) from fresh paint under ambient weathering (natural rain) conditions accumulated over one month, which are similar to those measured under the harshest conditions (presence of $\mathrm{NaCl}+\mathrm{HA}$ under UVA) in lab-simulated rain events (Olabarrieta et al., 2012). Tests on well-known commercial photocatalytic coating products (e.g. Pilkington Active ${ }^{\mathrm{TM}}$, which consists of a $12-15 \mathrm{~nm}$ thick nanocrystalline film of anatase $\mathrm{TiO}_{2}$ according to the manufacturer data) and experimental photocatalytic coatings demonstrate the slow but persistent release of $\mathrm{TiO}_{2}$ ENMs from these coatings under water flow. The cumulative release of $\mathrm{TiO}_{2}$ ENMs over four weeks $\left(0.06\right.$ to $4.11 \mathrm{mg} \mathrm{m}^{-2}$ for Pilkington Active ${ }^{\mathrm{TM}}$ and 0.12$20.07 \mathrm{mg} \mathrm{m}^{-2}$ for the experimental coatings) was dependent on the coating, as well as the aging conditions (e.g., water matrix and irradiation; Olabarrieta et al., 2012). Three mechanisms were suggested to explain the release of $\mathrm{TiO}_{2}$ ENMs from photocatalytic coatings: 1) agglomerates are stripped off of the coatings by water flow, 2) dispersion of $\mathrm{TiO}_{2}$ agglomerates occurs in the presence of $\mathrm{NaCl}$ and UV light, and 3) direct liberation of $\mathrm{TiO}_{2} \mathrm{ENMs}$ from siliceous matrices can occur as a consequence of its loosening due to mechanical damage of the paint (Olabarrieta et al., 2012). Being aware of these mechanisms is crucial to the understanding of the 
environmental behavior, fate and effects of the released ENMs. While the agglomerate stripping mechanism by water flow will lead to the emission of large $\mathrm{TiO}_{2}$ agglomerates which will likely settle out into the bottom sediments, both dispersion of ENM agglomerates and liberation of non-agglomerated ENMs from siliceous matrices will lead to more persistent suspension in the water column, resulting in transport over long distances. Despite the importance of ENM aggregation processes in controlling their environmental behavior and potential removal from the water column, recent studies have demonstrated that at low (ca. $\mathrm{ng}$ to $\mu \mathrm{g} \mathrm{L}^{-1}$ range) environmentally relevant concentrations, ENM aggregation becomes less important (Baalousha et al., 2015b) .

Other studies point out that the release rates of $\mathrm{TiO}_{2}$ and $\mathrm{SiO}_{2} \mathrm{ENMs}$ from façade coatings is very low (see values and details of experimental condition of each study in Table S2) and in most cases they are released as ENMs bound to large paint particles, which is likely to reduce the nano-scale effects (Al-Kattan et al., 2015; Al-Kattan et al., 2013; Kaegi et al., 2010; Olabarrieta et al., 2012; Zuin et al., 2013; Zuin et al., 2014). However, this may lead to hot spots of ENMs in sediments in stormwater detention ponds and in sediments in receiving water bodies. Higher release values (ca. 10-35\%) are typically reported for Ag ENMs (Kaegi et al., 2010; Künniger et al., 2014). Some studies have demonstrated the release of Ag ENMs from paint in the particulate form (Kaegi et al., 2010), whereas other studies did not find any particulate silver (Künniger et al., 2014). Künniger measured a loss of 10-35\% of Ag from paint based on measuring residual $\mathrm{Ag}$ in paint, and only $<1 \%$ based on analysis of $\mathrm{Ag}$ in the runoff (Künniger et al., 2014). They suggested that the released Ag may take different pathways to the environment other than runoff, such as atmospheric transport and migration to soil.

Some studies report an exponential decrease in the release of ENMs over time (Kaegi et al., 2010), whereas other studies found no trend in the concentration of the released ENM over time (Al-Kattan et al., 2015). Such decrease in released ENM concentrations would occur if initially loosely bound particles on the paint surface are washed off. Other studies reported an increase in the release of ENMs with aging due to loosening of the ENMs on the surface by destruction of organic polymer coatings by the UV irradiation (Al-Kattan et al., 2013).

Paint formulation (type and concentration of binder and concentration of calcite filler) is an important factor determining the release of $\mathrm{SiO}_{2}$ ENMs. A higher proportion of binder forms a suitable matrix to hold ENMs (e.g. $\mathrm{SiO}_{2}$ ) in paint, and thus adjusting paint formulation could reduce the release of ENMs to the environment (Zuin et al., 2014). Higher release of $\mathrm{Si}$, about 1.7 wt. \% of the $\mathrm{SiO}_{2}$ ENMs, for the paint formulated with a higher content of PVC (63\%), suggests that the $\mathrm{PVC}$ is a crucial factor for the release of $\mathrm{SiO}_{2} \mathrm{ENMs}$ from paint. Lower release 
of Si from paints with higher amounts of binder and less calcite filler among the paints with low PVC value (35\%) and no $\mathrm{SiO}_{2}$ ENMs were detected in the leachates from these paints (Zuin et al., 2014). However, the leachate $\mathrm{pH}$ in this study (ca. 7.8-8.5) was considerably higher than rainwater (ca. 4.5-6.0; Balasubramanian et al., 2001; Granat, 1972) and thus may not be representative of natural rain water conditions.

So far, there is no systematic investigation of the impact of temperature on the extent and rate of ENM release from paint and façade and some studies did not report the temperature under which the release experiments have been performed (Kaegi et al., 2008; Kaegi et al., 2010). Temperature is likely to be a crucial determining factor, especially in hot geographical locations, which may result in faster weathering (corrosion) of the paint, thus promoting enhanced release of ENMs.

\section{Release of incidental nanomaterials in the urban environment}

INMs are generated continuously in large amounts in the outdoor urban environment by automobiles, incinerators, smelters, power plants, and industries in urban areas (Buseck and Adachi, 2008; Kumar et al., 2014). INMs may be released from these sources in particle form or formed in the atmosphere as a product of the reaction of gaseous emissions, such as secondary organic aerosols (George et al., 2015; Kroll and Seinfeld, 2008). In the urban environment, the great majority of INMs are (at least initially) airborne, adding to a major background of naturally-occurring atmospheric NMs (Buseck and Adachi, 2008;;Hochella et al, 2012), and a lesser but still critical and growing amount of airborne ENMs. Airborne NMs occur in widely diverse settings across the globe, with least abundance (number concentrations) in the polar regions and highest abundance in urban areas, where anthropogenic sources dominate (Buseck and Adachi, 2008). Although NMs contribute a negligible portion of the total mass of particulate matter (PM), they are the dominant fraction in terms of particle number, reaching three orders of magnitude higher than larger particles (Kukutschová et al., 2011).

Numerous studies over the past two decades has focused on the ultrafine fraction $(\leq 100$ $\mathrm{nm}$ ) of atmospheric PM, traditionally referred to as the nucleation $(1-10 \mathrm{~nm})$ and Aitken (10 $100 \mathrm{~nm}$ ) aerosol modes. Although the terms "ultrafine particles" (UFP) and "airborne NMs" are sometimes used interchangeably, the latter frequently refers to ENMs and occasionally to particles smaller than $50 \mathrm{~nm}$ (Morawska et al., 2009). In this paper, we refer to airborne or atmospheric NMs as an encompassing term for both ENMs and INMs. 
The majority of NM studies in the urban environment have been performed in the context of air quality and has focused on measuring particle size and number concentration, with some efforts addressing the more challenging issues of chemical composition and transformations. There have been great advancements brought by real-time instrumentation, such as aerosol mass spectrometry and aerosol time-of-flight mass spectrometry, used to measure sizeresolved concentrations of non-refractory components of PM (e.g., organics, sulfates, nitrates, ammonium; Healy et al., 2009; Nash et al., 2006; Reinard et al., 2007). Some effort has also been put into quantifying bulk metal concentrations in different size fractions of PM (e.g., $\mathrm{PM}_{10}$, 2.5,1 and ultrafine), using methods such as inductively-coupled plasma atomic emission spectroscopy/mass spectrometry (Wang et al., 2013). Over the last decade, a significant number of researchers have applied scanning and transmission electron microscopy techniques coupled with elemental analysis capability to characterize single-particle chemistry, morphology, and crystallinity, which are likely to be crucial factors in determining their environmental fate, behavior, and effects (Morawska et al., 2009; Quadros and Marr, 2010; Sanderson et al., 2014). However, as is the case for aquatic and terrestrial environmental compartments (Montano et al., 2014; von der Kammer et al., 2012), full chemical characterization (detection and quantification) of atmospheric NMs represents a significant challenge to the scientific community (George et al., 2015; Grassian, 2008).

In the urban environment, INMs (and some ENMs) can be released by vehicles via engine combustion exhaust, brake pad and tire abrasion, and paint and self-cleaning surface degradation (Table S3). While vehicular exhaust emissions are mostly composed of individual INMs, non-exhaust emissions and other sources are more likely to emit NMs that are attached to larger particles. In urban environments, traffic-related emissions (exhaust and non-exhaust) are the dominant source of particles by number (Kumar et al., 2011; Thorpe and Harrison, 2008) and over $99 \%$ of particle emissions fall under $300 \mathrm{~nm}$ (Kumar et al., 2014). Traffic-related PM constitutes a significant source of diffuse metal pollution in urban waters (Sanger et al., 1999). Some studies have identified and characterized metal-based NMs in traffic-related emissions (Table S3; Adachi and Tainosho, 2004; Barrett et al., 2010; Kukutschová et al., 2011; Mirabedini et al., 2012). These studies have identified different phases of metal-containing NMs including zero-valent metals, metal oxides, chromates, carbonates, phosphates, alloys, etc. within nanoscale as well as larger particles (Table S3).

There has been an extensive focus on studying exhaust emissions, but non-exhaust emissions have also been found to contribute to particulate matter in urban cities. Omstedt et al. (2005) estimated that break and tire wear may release between 6 and $\left.30 \mathrm{mg}^{(v e h i c l e ~} \mathrm{km}\right)^{-1}$, 
compared to 20 - $30 \mathrm{mg}$ (vehicle $\mathrm{km}^{-1}$ for exhaust emissions (Omstedt et al., 2005). For instance, zinc oxide is added as an activator during the vulcanizing process, comprising 0.4$4.3 \%$ of the resulting tire tread (Smolders and Degryse, 2002), and $\mathrm{Zn}$ from tire dust is a significant pollutant in soil (Councell et al., 2004; Smolders and Degryse, 2002), air (Rogge et al., 1993), street dust (Fergusson and Kim, 1991), and urban runoff (Davis et al., 2001). Tire tread contains other metals such as $\mathrm{Mn}, \mathrm{Fe}, \mathrm{Co}, \mathrm{Ni}, \mathrm{Cd}$, and $\mathrm{Pb}$ (Fukuzaki et al., 1986). Omstedt et al. (2005) found tire dust to be a minor contributor of particulate matter when compared to break wear. Brake dust has been recognized as a significant source for $\mathrm{Cu}, \mathrm{Sb}$ and $\mathrm{Ba}$ in aerosols, and contributed $47 \%$ of the total loading for $\mathrm{Cu}$ in urban runoff (Sternbeck et al., 2002). Yellow paint contributed from 0.3 to $1.0 \%$ of the airborne dust in Nigata, Japan (Fukuzaki et al., 1986). These and other studies have addressed traffic-related PM emissions in the context of air quality and human health, but only a few studies have focused on the occurrence and the materials properties of the NM fraction of these releases (Thorpe and Harrison, 2008; Uibel et al., 2012).

\section{Pathways and transformations of NMs in the urban environment}

Once primary NMs are released from nano-enabled products or incidentally created, they can enter several pathways in the outdoor urban environment. The pathway most important to potential human health effects is the atmospheric PM pathway (Grobéty et al., 2010). PM may be present as individual particles (also known as externally mixed) or attached to larger particles (also known as internally mixed). Atmospheric particles may become coated with semi-volatile organic matter (SVOCs) and reactive volatile organic compounds (VOCs) as they age. PM presents a large surface area that provides sites for a variety of heterogeneous photochemical reactions in the atmosphere, which are primarily driven by the presence of free radicals and UV radiation and are likely to be mediated by wet (cloud, fog) conditions (e.g., acid-base reactions) (George et al., 2015). The physical and chemical characteristics of evolving PM in the atmosphere may vary greatly depending on the source and subsequent transformations in the atmosphere.

The transport and fate of NMs in the atmosphere is largely dictated by their size. Particles smaller than $\sim 120 \mathrm{~nm}$ (Knudsen number < 1 ) are much more susceptible to diffusion due to Brownian motion than to gravitational settling, so these particles are not lost from the atmosphere by deposition. Rather, the small residence time of NMs in the atmosphere is due to the fact that they quickly grow by coagulation to each other and to larger particles, resulting in 
an increase in particle size with a decrease in the number concentration (Clarke et al., 2004; Gidhagen et al., 2004; Seinfeld and Pandis, 2012). NM size growth rate is dependent on chemical and physical conditions of the particles and the surrounding environment. Nie et al. (2004) reported particle growth rates averaging $14 \mathrm{~nm} \mathrm{~h}^{-1}$ for particles $30-50 \mathrm{~nm}$ in diameter during dust events (averaging about $300 \mu \mathrm{g} \mathrm{m}^{-3} \mathrm{PM} 10$ ) and about $7 \mathrm{~nm} \mathrm{~h}^{-1}$ on non-dust days (averaging $64 \mathrm{\mu g} \mathrm{m}^{-3} \mathrm{PM10}$ ). Once NMs grow into or become attached to larger particles, they reach the aerosol accumulation mode $(\sim 100-2,500 \mathrm{~nm})$, thus called because the removal mechanisms (e.g., deposition by diffusion and gravitational settling) are not as effective in this size range. $\mathrm{PM}$ in this size range can remain in the atmosphere for extended periods of time, from days to weeks (Kreidenweis et al., 1999) and thus are subject to long-range (transboundary to inter-continental) atmospheric transport. For example, PM generated by dust storms in northern China has been reported to reach the Pacific Ocean and beyond (Han et al., 2015), and Saharan desert dust is known to reach Europe (Salvador et al., 2013), and well as North and South America (Prospero, 1999a; Prospero, 1999b) in significant concentrations.

Accumulation mode particles can grow further by condensation of low-volatility compounds, or shrink by evaporation if the vapor phase concentration is low. These two processes can induce variation in particle size distribution but not the overall number concentration (Zhang et al., 2005). These particles can also become diluted by mixing with cleaner air. For example, vehicular exhaust particles may mix upward with less polluted air, leading to a reduction in the number concentration and generally an increase in particle size (Zhang et al., 2005). This mixing is dictated by local meteorological conditions in cities, such as wind speed and direction, and the atmospheric stability within the urban canopy layer, which extends to about twice the average building height (Goel and Kumar, 2015).

NM-containing PM can be removed from the atmosphere through dry or wet deposition, processes that can typically take several days, or through further growth into the coarse aerosol mode $(1-2.5 \mu \mathrm{m})$ which results in deposition by gravitational settling (George et al., 2015; Seinfeld and Pandis, 2012). Deposited PM is likely to be internally and externally mixed with NMs and their aggregates. Dry deposition results in the removal of larger particles by gravity, whereas smaller particles can be removed from the atmosphere more efficiently by wet deposition. Gunawardena et al. (2013) demonstrated that bulk (wet plus dry) deposition contains a higher percentage of smaller particles compared to dry deposition, which is attributed to the ability of rainfall to scavenge fine particles in the atmosphere which do not easily settle under gravity due to buoyancy and drag forces (Gunawardena et al., 2013). 
Due to the dominance of impervious surfaces in the urban environment, significant amounts of NMs are expected to deposit on those surfaces through both wet and dry deposition. Once particles deposit on impervious surfaces, they may get re-suspended into the atmosphere for various lengths of time or they may be washed away with rainwater. Atmospheric deposition may also result in these NMs reaching green spaces and/or soils and waterways, where they will add to the INMs and ENMs already in place.

Once NMs and their aggregates are mixed with rainwater, they become susceptible to transformation processes typically occurring in aquatic systems (Lowry et al., 2012; Peijnenburg et al., 2015). Depending on the rain water chemistry and NM properties, these transformations may result in loss or replacement of surface coating formed in the atmosphere, further aggregation of NM, release of NMs by disaggregation of NM aggregates or detachment from the carrying substrates, dissolution and release of ionic species, precipitation of released ionic species, sulfidation in anoxic waters (e.g. stormwater pipeline; (Kaegi et al., 2013)), sedimentation, and advective transport with the stormwater runoff. Additionally, the rates of these transformations likely depend on particle/water ratio, and duration of dry period and intensity and duration and intensity of storm events, due to the concentration-dependent behavior of particles and ENMs (Baalousha et al., 2015b). However, these processes have not been specifically studied for urban dust particles (NMs and PM deposited on impervious surfaces).

In urban areas, in many parts of the developed world, water runoff is typically retained in stormwater ponds to mitigate flooding, where NMs may undergo further transformations as discussed above. However, stormwater ponds discharge their water to adjacent surface water bodies without any treatment to remove NMs. Stormwater ponds are passive units that remove contaminants (including NMs) by passive sedimentation. Aggregated NMs and those attached to larger substrates are likely to be removed in stormwater ponds by sedimentation, where they may undergo further transformations (e.g., sulfidation) due to the anoxic conditions in the sediment. If released by disaggregation, NM may get re-suspended in the water column or travel with groundwater through the underlining soil. Individual NMs (either released from aggregates by disaggregation or sterically stabilized NMs) in the water column may remain suspended for extended periods of time and can be discharged to the receiving surface waters. Dissolved species released by dissolution of NMs will be either released to the receiving surface waters or travel to groundwater, another important area that deserve further in-depth investigation. For instance, Duester et al. (2014) suggested that in cities with a state of the art sewer infrastructure, a fraction of NMs will be directly discharged to surface waters or to 
treatment facilities (e.g. constructed wetlands) through stormwater overflow during heavy rain events. Here, we further suggest that the stormwater system in general acts as a major vector of NMs from the urban environment; stormwater detention/retention ponds also act as a conveyer of NM to the environment (surface water, sediment, and groundwater). Nevertheless, the literature is short on studies investigating the occurrence and behavior of NMs in stormwater system.

The potential transformations of NMs in stormwater systems discussed above have not received much attention. However, NM transformations have been extensively investigated in the context of WWTPs, as exposure models predicts that WWTPs are one of the major conveyers of ENMs to surface and potentially groundwater. Numerous studies have demonstrated that the majority of ENMs (>95\% by mass) in WWTPs are removed in the biosolids and only a small fraction will be released with the effluent to the receiving surface waters (Kent et al., 2014; Kiser et al., 2009; Ma et al., 2014a; Westerhoff et al., 2011). Also numerous studies demonstrated the sulfidation of different types of ENMs (e.g. Ag and $\mathrm{ZnO}$ ) in WWTPs, limiting the release of ionic species (Kim et al., 2014; Kim et al., 2010; Levard et al., 2012). However, due to the obvious differences in the chemistry of stormwater and wastewater, NMs should be expected to undergo different transformations in stormwater systems compared to waste water systems and within WWTPs (Barton et al., 2015; Brar et al., 2010; Doolette et al., 2013; Kaegi et al., 2013; Kaegi et al., 2011), and the rates of these transformation processes are likely to be different, requiring further research. For instance, urban water runoff systems have lower concentrations of sulfide compared with waste water systems including within WWTPs. Thus, sulfidation of metal and metal oxide NMs (e.g. Ag, CuO, ZnO; (Baalousha et al., 2015a; Levard et al., 2011; Ma et al., 2014a; Ma et al., 2013; Ma et al., 2014b)) is less likely to occur in stormwater runoff compared with WWTP, which may not totally prevent NM dissolution and release of ionic species (Baalousha et al., 2015a).

\section{Figure 1.}

\section{Case study 1: Nanomaterials in atmospheric particulate matter}

As suggested above, atmospheric PM is a widespread form of air pollution that is of great concern due to its adverse effects to the environment, climate, and health. In 2013, the International Agency for Research on Cancer (IARC) classified PM as carcinogenic to humans. Over the past three decades, a large body of scientific literature has provided evidence of 
associations between short-term (hours, days) and long-term (months, years) exposure to PM and increased mortality and hospitalization, attributed to cardiovascular and respiratory diseases (WHO, 2013). $\mathrm{PM}_{2.5}$ (fine particulate matter, aerodynamic diameter equal or less than $2.5 \mu \mathrm{m}$ ) is associated with a stronger risk factor than $\mathrm{PM}_{10}$ (aerodynamic diameter equal or less than $10 \mu \mathrm{m}$ ) in terms of cardiopulmonary mortality (Beelen et al., 2014). Recently, $\mathrm{PM}_{2.5}$ was estimated to lead to 3.3 million premature deaths per year worldwide (Lelieveld et al., 2015). Airborne NMs can reach the alveolar region of the respiratory system and translocate via the bloodstream to other organs, including the heart and brain (HEI Review Panel on Ultrafine Particles, 2013; Oberdörster, 2010), which indicates that the NM fraction of PM may be responsible for much of its observed toxicity. Airborne NMs can interact strongly with other toxins due to their large specific surface area per unit volume. Kumar et al. (2010) suggest that particle number concentrations of PM are an important metric to represent the toxic effects, and that particle composition and diameter could play a major role in the pathogenesis (Kumar et al., 2010). One needs to keep in mind that particles less than about $50 \mathrm{~nm}$ in size can make up roughly $90 \%$ of all PM particles by number (Buseck and Adachi, 2008).

There is much to learn from the chemical composition, mineralogy, and properties of NMs in atmospheric particles. In this context, electron microscopy (EM) techniques, such as scanning transmission electron microscopy (STEM) and scanning electron microscopy (SEM), coupled with EM accessory capabilities such as energy-dispersive X-ray spectroscopy (EDX) and selected area electron diffraction (SAED), have been recognized by the scientific community as powerful tools to provide detailed information on NM properties. TEM micrographs with image analysis provide information on NM size and morphology; EDX enables measuring NM elemental composition; and SAED (similar to x-ray diffraction, XRD) enables the identification of the crystal structure of the particle (Capannelli et al., 2011; Quadros and Marr, 2010; Kim and Hochella, 2015).

In this case study, we applied transmission electron microscopy (TEM)-SAED/EDX to characterize $\mathrm{PM}_{2.5}$ samples collected during a hazy day and a clear day in Shanghai, China, by using a low-volume sampler (Minnivol_Tactical Air Sampler) at a rate of $8 \mathrm{~L} \mathrm{~min}^{-1}$. The metal concentrations in $\mathrm{PM}_{2.5}$ were analyzed by ICP-MS and summarized in Table S4. Metal concentrations are several folds ( 3 to 97 folds) higher during a hazy day compared with a clear day. Besides fly ash and soot, metal oxides were found to be ubiquitous in $\mathrm{PM}_{2.5}$, among which iron oxides were most frequently found. Iron oxide NMs had sizes in the range of 5-150 nm and were found to be typically coated with carbonaceous materials or embedded in a carbon matrix. Figure 2 shows an image and the elemental maps of typical aggregates found in the $\mathrm{PM}_{2.5}$ 
collected during the hazy day, which contained iron oxides (Figure $2 \mathrm{c}$ and $2 \mathrm{~h}$ ), lead sulfide (Figure $2 \mathrm{f}$ and $2 \mathrm{i}$ ), and calcium silicate (Figure 2c, $2 \mathrm{e}$, and $2 \mathrm{~g}$ ). Using SAED, we determined that iron oxides had d-spacings of 4.8 and $2.9 \AA$, which is comparable to those of the $\left(\begin{array}{lll}1 & 1 & 1\end{array}\right)$ and $(2$ 20 ) planes of magnetite (Bosi et al., 2009). Magnetite is a widely used material for fabricating steel and it is also identified in fly ash derived from high-temperature fossil fuel combustion. Additionally, magnetite has been found in urban dust samples (Elzinga et al., 2011; Xia et al., 2008; Zhang et al., 2011) and in vehicular exhaust emissions (Abdul-Razzaq and Gautam, 2001). We found magnetite NMs embedded in $\mathrm{PM}_{2.5}$ samples collected during both hazy and clear days in Shanghai, indicating that they likely originated from vehicle exhaust. However, the possible input from coal ash burning and industrial iron/steel production cannot be ruled out.

Elevated lead concentrations were found in $\mathrm{PM}_{2.5}$ taken in both hazy and clear days. It is notable that $\mathrm{Pb}$ concentration in $\mathrm{PM}_{2.5}$ samples taken during the hazy day $\left(900 \mu \mathrm{g} \mathrm{m}^{-3}\right)$ exceeded the World Health Organization (WHO) guideline $\left(500 \mu \mathrm{g} \mathrm{m}^{-3}\right)$. Galena (PbS) NMs (ca.100-200 nm) in cubic or rounded shapes were found in the $\mathrm{PM}_{2.5}$ samples collected on both clear and hazy days (Figure 2). The occurrence of galena may be best explained as the primary form of lead associated with mining waste (Hemphill et al., 1991) and can be released by leadassociated smelters (Beeston et al., 2010). Smelter activities are also implicated because lead has been banned as a gasoline additive in China. It should be noted that the annual concentration of atmospheric $\mathrm{Pb}$ in China decreased by $74 \%$ due to this ban (Li et al., 2000). However, coal combustion is now also a major source of anthropogenic atmospheric lead (Duan et al., 2012).

This case study demonstrates an application of TEM-SAED/EDX for the characterization of PM samples according to size, morphology, chemical composition, and crystal structure to give insights into their potential sources and health implications.

Similar studies as the one just described provide interesting information for comparison. Li et al. (2011) applied TEM-EDS for single-particle analysis of PM collected in cities in northern China and particles were classified in six groups based on their chemical makeup, shape, and crystallinity: S-rich (OM/soot), fly ash, metal, crustal mineral, Ca-S/N, and Na/K-S/N. They found that sulfur-rich INMs were dominant in hazy-day aerosols, but mineral dusts were dominant on clear days. SEM analysis of PM collected in a traffic tunnel revealed that soot made up the majority of the particles (Ancelet et al., 2011). These carbonaceous species formed large aggregates made up of 30-100 nm spherules. Inorganic elements such as $\mathrm{Fe}, \mathrm{O}, \mathrm{Na}, \mathrm{S}, \mathrm{Al}$ and $\mathrm{Zn}$ were found to be interspersed in soot that originated from non-exhaust processes like brake and tire wear and road dust resuspension. Soot aggregates, minerals and fly ash were identified 
as dominant anthropogenic NMs in $\mathrm{PM}_{2.5}$ in Guangzhou, China (Feng et al., 2009). Finally, based on an analysis of 834 individual aerosol particles also collected over the city of Shanghai, polymeric organic compounds, soot, tar balls, and biogenic particles were found to be the main carbonaceous constituents in this particular urban environment (Fu et al., 2012).

\section{Figure 2}

\section{Case study 2: Nanomaterials in stormwater ponds}

Urban stormwater ponds may receive NMs from multiple sources via stormwater runoff and wet/dry atmospheric deposition. The original sources include industrial emissions, exterior façades or painted surfaces, vehicles (exhaust and non-exhaust emissions), among others. However, the presence and fate of NMs within stormwater ponds has been generally overlooked, despite the significance of stormwater ponds as an important man-made hydrogeochemical feature in the urban environment and as a conveyer of contaminants to surface waters, soils and groundwater. For instance, the number of stormwater ponds across the United States has been estimated to be between 2.6 to 9.0 million with densities in some areas exceeding five per $\mathrm{km}^{2}$. Therefore, their impact is comparable in magnitude to that of larger reservoirs, both in term of surface area and sedimentation (Renwick et al., 2006).

To demonstrate the occurrence and types of NMs in stormwater ponds (Pond description and characteristics are summarized in Table S5), something that to our knowledge has never been attempted before, water and sediment samples were collected from both stormwater ponds with the surrounding high density (HD) urban development and with surrounding green space (GS) within the city limits of Durham, North Carolina, USA (Figure S1). Water $(<0.45 \mu \mathrm{m}$; Table S6), suspended particulate matter and sediment samples (Figure S2-S3) were analyzed for metal concentrations. Detailed information of the sampling and metal concentrations is described in the supporting information. Briefly, metal concentration in the water fraction $<0.45$ $\mu \mathrm{m}$ are generally low (Table S6). SPM and sediments are rich in metals (Figure S2) and SPM have generally higher metal concentration compared to sediments from the same pond, suggesting that metals occur mainly in particulate form (e.g. NMs and micron-sized particles) in stormwater ponds. For instance, taking $\mathrm{Zn}$ as example, although $\mathrm{Zn}$ was only detected in water samples $(<0.45 \mu \mathrm{m})$ of two ponds, elevated $\mathrm{Zn}$ concentrations were found in both the SPM and sediment samples in all ponds. This indicates that metals in stormwater ponds, such as $\mathrm{Zn}$, occur mainly in a particulate form (e.g. NMs and micron-sized particles) in the SPM, and these 
particles settle out from the water column to the sediments. Below we focus on direct identification of the NMs found using STEM, EDS, and SAED.

Various nano-sized iron oxides (hematite, goethite and magnetite; see Figure 3a-e) were identified in suspended particulate matter (SPM), that is, in the water column of the pond, and in the pond sediment. More interestingly, Figure $\mathbf{3 g}$ shows an aggregate of pseudo-hexagonal platelets. These NMs have minor sulfur content with d-spacings of $2.49 \AA$ and $1.46 \AA$, which is very close to that expected for green rust $\left(\mathrm{Fe}_{2}\left(\mathrm{OH}, \mathrm{SO}_{4}\right)_{4.88}\right.$ (Johnson et al., 2015). Given the specific morphology and element composition (Christiansen et al., 2009; Johnson et al., 2014; Wankel et al., 2012), this green rust most likely formed in a reduced environment in the stormwater pond, which is consistent with iron sulfide NMs also found in the sediment of this pond. Green rust platelets are known to be very unstable under oxic conditions, which helps explain why they are rarely observed although they are thought to be relatively common. However, they are also highly reactive (Choi and Batchelor, 2008; Hansen, 2001; Zegeye et al., 2014).

\section{Figure 3}

Titanium oxides, including anatase (Figure $\mathbf{4 a}$ and b) and rutile (Figure 4d), were found in all samples taken from stormwater ponds. Figure $\mathbf{4 a}$ shows an example of anatase found in colloidal fractions. The HRTEM image (Figure 4b) together with the SAED pattern (Figure 4c) show that these particles are anatase with primary size of $10-20 \mathrm{~nm}$. Aggregates of larger anatase particles were also ubiquitous in stormwater ponds. Rutile was also ubiquitous in SPM and sediments collected from HD stormwater ponds. For example, Figure 4d illustrates a large aggregate of rutile nanorods with primary particle size of 10-100 nm width. In addition, trace elements such as $\mathrm{Al}, \mathrm{Cr}, \mathrm{Fe}$, and $\mathrm{Pb}$ were observed to be associated with rutile aggregates. The occurrence of $\mathrm{TiO}_{2} \mathrm{NMs}$ in all types of stormwater ponds is not surprising given that they can occur as natural NMs, but also due to its wide production and use in the outdoor urban environment in paints and in self-cleaning surfaces.

\section{Figure 4}

Zinc oxides NMs were identified in the colloidal fractions with a primary size of about 100$200 \mathrm{~nm}$ (Figure 5a). The crystal structure was consistent with zincite, as identified by SAED 
which showed a d-spacing of $2.47 \AA$ matching that of the zincite (101) plane (Figure $5 \mathbf{b}$ ). In addition, $\mathrm{ZnO}$ was only found in SPM and sediments taken from two stormwater ponds (HD-C and GS_C) with primary particle size of $50-200 \mathrm{~nm}$, and the DO contents in these two ponds are higher compared to other stormwater (Table S1). The occurrence of $\mathrm{ZnO}$ in the water column in the stormwater pond is not surprising, because $\mathrm{ZnO} N M s$ are widely used in a range of applications, such as fillers in rubber industry, as component of creams, as powders in the pharmaceutical and cosmetic industries, and as absorbers of UV radiation in the sunscreen and textile industries (Kolodziejczak-Radzimska and Jesionowski, 2014). It is also used as an additive in tire rubber, released to roadways with wear.

\section{Figure 5}

ZnS NMs were detected in all the SPM and sediment samples from urban HD and GS ponds. The ZnS NMs, as small as $5 \mathrm{~nm}$ in diameter (Figure 5f), are typically aggregated resulting in grains that are $100 \mathrm{~nm}$ to a few hundred $\mathrm{nm}$ in size (Figure 5e). The observed ZnS NMs are in random crystallographic orientations, which lead to a diffuse ring pattern in the SAED as shown in Figure $\mathbf{5 g}$. Observed d-spacings are 3.11, 1.91 and $1.63 \AA$, matching sphalerite (111), (220) and (311) repeats, respectively (Skinner, 1961). Trace metals, including $\mathrm{Al}, \mathrm{Fe}, \mathrm{Co}, \mathrm{Cu}$ and $\mathrm{Pb}$ were found associated with sphalerite aggregates.

In these ponds, the occurrence of ZnS NMs may result from the sulfidation of ZnO NMs via bacterial sulfate reduction. Also, it has been shown in previous studies (Ma et al, 2013; ; Hochella et al., 2005) that ZnO NMs readily transformed to secondary, minute ZnS NMs when exposed to sulfide under anoxic environments. In the ponds sampled for this study, anoxic niches likely developed within stormwater ponds where surface runoff was mild. We also observed apparent methane seeps suggestive of methanogen activities in GS-A, GS-B, and HD-B.

Soot aggregates with diameters of a hundred nanometers up to 1 micron were observed in the SPM and sediment samples in all ponds. These carbon-rich particles are often associated with trace metals, such as $\mathrm{Al}, \mathrm{Fe}, \mathrm{Mn}, \mathrm{Cu}$, and $\mathrm{Zn}$. Furthermore, in SPM and sediments from HD-D, we found $Z r$ - and Si-rich NMs with a d-spacing of $3.30 \AA$, matching the zircon d-spacing for (200). These zircon-NMs showed the primary size of 100-200 nm (Figure S5a), with association of trace amounts of $\mathrm{Al}, \mathrm{Fe}, \mathrm{Co}, \mathrm{Cu}, \mathrm{Pb}$ and $\mathrm{Bi}$. Zircon is an accessory but very important mineral occurring in igneous, metamorphic and sedimentary rocks, such as coal, and 
it is highly resistant to weathering. The zircon in our samples may be from coal, in that it has been reported in coals (Wells et al., 2005), and its association with trace amounts of $\mathrm{Bi}$ and $\mathrm{Pb}$ suggest their coal-related origins.

$\mathrm{CePO}_{4} \mathrm{NMs}$ were found in most of the urban pond samples (Figure S5c), which could result from the weathering of Ce-bearing minerals such as allanite $\left[\mathrm{Ce}_{2}(\mathrm{Al})_{3}(\mathrm{SiO})_{4} \mathrm{OH}\right.$ ]. Biotransformation of $\mathrm{CeO}_{2}$ to $\mathrm{CePO}_{4}$ could be another possibility, and the dissolution of $\mathrm{CeO}_{2}$ into $\mathrm{Ce}^{3+}$ and precipitation with phosphate can result in the occurrence of $\mathrm{CePO}_{4}$ around the roots of plants (Zhang et al., 2012). These $\mathrm{CePO}_{4} \mathrm{NMs}$ are associated with $\mathrm{Fe}, \mathrm{Mn}$ and $\mathrm{Cu}$.

Not surprisingly, most NMs from HD and GS stormwater ponds discovered and described above are observed in both the SPM and pond sediments. For example, zinc oxides, magnetite, and soot would not likely be natural components of the underlying pond soil, but most likely added to the ponds by atmospheric deposition or incoming surface runoff. Therefore, they start in the SPM, but aggregation will help them eventually reach the sediment below. Other NMs observed, like zircon, hematite, goethite, sphalerite, and green rust, may be from the underlying bedrock or soil forming processes, in which case we would not expect them to be in the SPM except due to entrainment of bottom sediment into the water column during excessive water flow (e.g., during severe storms). However, except for green rust, they could also have been transported into the ponds via atmospheric or surface runoff pathways.

Those NMs in the SPM of the stormwater ponds will be transported to surface waters down hydrologic gradient with water discharge, resulting in exposure to a wide range of environmental organisms downstream, or through groundwater flow. It should also be kept in mind that stormwater ponds are designed to be "passive treatment systems", which have been used largely to mitigate flooding by increased urban runoff, but also to prevent contaminants from entering surface waters. According to regulations in most urban areas, these ponds are supposed to be dredged to remove sediments that could provide metals of concern to downstream environments (e.g., $\mathrm{Pb}, \mathrm{Zn}, \mathrm{Cu}$, and $\mathrm{Co}$ in the examples described here). However, this is rarely the case and often they are not dredged. If untreated, contaminants (including NMs) that accumulate or are generated in stormwater ponds have a downstream disruption/pollution potential.

\section{Case study 3: PGE NMs in the environment}

This case study discusses the data available in the literature on source, release, environmental fate and potential impact of PGE NMs. Catalytic convertors containing platinum 
group elements (PGE, e.g. Pt, $\mathrm{Pd}$ and $\mathrm{Rh}$ ) were introduced with the purpose of reducing the emission of pollutants such as $\mathrm{CO}$ and $\mathrm{NO}_{\mathrm{x}}$ from exhaust gases of the vehicles, by converting them to less toxic gases such as $\mathrm{CO}_{2}$ and $\mathrm{NO}_{2}$ (Ravindra et al., 2004). However, the emission of Pt derived from the abrasion and deterioration of catalytic converters has resulted in an increase in airborne particulate matter with size $<2.5 \mu \mathrm{m}\left(\mathrm{PM}_{2.5}\right)$ (Morton-Bermea et al., 2014), in surface waters like stormwater ponds, rivers and lakes, especially in urban areas (Prichard et al., 2008), and even more widely throughout the urban environment (Barbante et al., 2001; Barefoot, 1999; Bowles and Gize, 2005; Cinti et al., 2002; Ravindra et al., 2004).

Early efforts to study air born particles focused on the occurrence of $\mathrm{Pt}$ in $\mathrm{PM}_{2.5}$ and $\mathrm{PM}_{10}$, and several studies have concluded that distribution patterns of PGE among PM size fractions were inconsistent (Gómez et al., 2001; Wiseman and Zereini, 2009) because these studies focused on the total PGE element concentration rather than on the form of PGE elements in particulate matter. More recently, several studies have demonstrated the occurrence of PGE as NMs. PGE's have been shown to occur in road dust and gully waste as NMs and micron sized particles attached to larger particles (wash coat of catalytic converters), and the source of these particles have been attributed to their release from catalytic converters. These PGE NMs and sub-micron sized particles can be detached from larger particles, becoming separate particles/NMs (25-300 nm in size; Prichard and Fisher, 2012). Thus, once detached from the wash coat, the PGE particles/NMs may travel through the surface environment as atmospheric or aqueous NMs. However, identifying individual PGE particles/NMs in sediments and surface waters further from the road dust source would be difficult due to their low concentrations. PGE NMs may also form aggregates and settle in surface waters. Significant contamination of PGE has been observed in sediments located in close proximity to storm drains following the sequence Pt (10.3-24.5 $\left.\mathrm{ng} \mathrm{g}^{-1}\right)>\operatorname{Pd}\left(5.9-12.6 \mathrm{ng} \mathrm{g}^{-1}\right)>\mathrm{Rh}\left(0.82-2.85 \mathrm{ng} \mathrm{g}^{-1}\right)>\operatorname{lr}(0.11-0.23 \mathrm{ng}$ $\mathrm{g}^{-1}$ ) (Sutherland et al., 2015). In this study, enrichment factors follow the sequence $\mathrm{Rh}(25.3)>>$ $\mathrm{Pf}(6.9)=\mathrm{Pt}(6.8)>>\operatorname{Ir}(2.3)$ indicating significant anthropogenic contamination of $\mathrm{Rh}$, Pt, and $\mathrm{Pd}$ and a geogenic source of Ir. These findings suggest that PGE NMs (and other NMs released in the urban environment) are likely to end up in sediments in stormwater detention ponds and receiving creeks; however, this hypothesis requires further investigations.

PGE-bearing NMs have been also found in the feathers of raptors where laser ICP-MS analysis indicate that nanometer sized (dominantly 5-15 nm together with a few larger particles in the 2.5-5 $\mu \mathrm{m}$ range) particles of Pt or Pd can be attached (Jensen et al., 2002). This study demonstrates a bioavailability/mobility gradient of $\mathrm{Pd}>\mathrm{Rh} \geq \mathrm{Pt}$ as $\mathrm{Pd}$ contamination of feathers is both external and internal, whereas $\mathrm{Pt}$ and $\mathrm{Rh}$ contamination is predominantly external 
(Jensen et al., 2002). Further, PGE NMs are far from inert in the surface environment; as the PGE particles are dispersed, they may dissolve (Bowles and Gize, 2005). Pt, Pd, and Rh form soluble chloride complexes and the addition of salt to roads during icy conditions may facilitate the solubility of these PGE particles (Cosden et al., 2003). Consideration of the possible health effects of PGE from vehicle exhaust has centered on inhalation of the particles or absorption through the skin (Bowles and Gize, 2005). Pt has been observed to cause adverse health effects that have been summarized elsewhere (Ravindra et al., 2004). Intake from drinking water or from food produced using PGE-bearing water should now also be investigated (Bowles and Gize, 2005).

This case study demonstrates the release of PGE NMs from catalytic convertor technology, their occurrence in atmospheric particulate matter as well as in stormwater runoff and receiving surface waters, and their interaction with the biosphere. This case study provides a good example of the potential behavior/interactions of INMs and ENMs in the environment, and the potential environmental implications of nanotechnologies in an urban setting.

\section{Environmental Implications and Future Directions}

Clearly, nanotechnologies are widely used in the outdoor urban environment in a vast range of applications. These applications are expected to increase in the near future and to significantly increase in the long-term, because such applications are practically endless. Nanotechnology continues to infiltrate the vital economic sectors of medicine, security, sanitation/environment, construction, electronics, and transportation, all sectors that are strongly present in urban areas. However, as discussed above in the Introduction and Applications sections of this paper, relatively little attention has been given to the release and fate of ENMs and many types of INMs from these emerging applications as they are dispersed into a very wide range of outdoor urban environmental compartments, and then often into surrounding and sometimes distant non-urban areas. Even now, released and transformed ENM and INM populations abound in outdoor urban areas. In addition, complex chemical, structural, size, and shape factors of ENMs and INMs are expected to play an "invisible", yet significant role in the human quality of life in these urban settings. It is well known that within the nanoscale, even subtle changes in size and shape of NMs can result in dramatic differences in environmentally relevant reactions (Madden et al., 2006; Hochella et al., 2012).

Likewise in the atmospheric urban compartment, where many types of nanomaterials have been monitored and tracked for some time, new ENM technologies will modify this domain, and 
the connections between the atmospheric and other compartments (e.g. the vast array of urban surfaces, urban plants and soils, and water runoff systems, including stormwater ponds) should be explored and understood. In addition, INMs in urban settings originating in both localized (e.g., factory) and overarching (e.g., a city-wide transportation) urban systems and components continue to evolve from legacy all the way to future enterprises. Stepping back and contemplating this in a wider context, we remind ourselves that the general field of urban geochemistry is celebrating its third decade of study. Yet this field is far from mature (Lyons and Harmon, 2012). On the other hand, the study of the environmental impacts of urban NMs is clearly in its infancy.

Based on both literature review and experimental analysis, here we have identified and reported a wide variety of urban NMs in atmospheric particulate matter (PM), dust on impervious surfaces, stormwater pond waters and sediments, and in urban surface waters such as urban lakes. Certain basic conclusions can already be put forward based on this information that were not clearly apparent before. For example, all three case studies described above suggest that stormwater ponds act as an important conveyer for a wide range of NMs in the urban environment. Interestingly, this includes stormwater ponds in urban green space areas. NMs may be transported through urban stormwater flow, but also through atmospheric deposition. Given the extraordinary numbers of stormwater ponds in the United States and around the world, the occurrence and transport of NMs through stormwater ponds is likely to have a significant impact on the biogeochemistry or aquatic ecosystem of the broader watershed; this warrants further study on the occurrence, behavior and environmental risks of NMs in urban stormwater ponds. This is just one of the many aspects of hydro-engineering and geology of water movement in urban areas (Wong et al., 2012). Many other aspects need to be carefully examined, such as stormwater runoff sewers that empty directly into streams and rivers, as well as runoff that is directed into wastewater treatment plants.

Long-term research in the emerging field of outdoor urban nanomaterials should include, but not necessarily be limited to: 1) continuing to identify, characterize, and potentially quantify ENMs and INMs in all urban environmental compartments (i.e., air, impervious surfaces, and surface waters); 2) tracking the movement and transformations of ENMs and INMs within and between these compartments in the full range of urban environments; 3) investigating the fate, pathways, and transport of urban NMs into surrounding non-urban environments; 4) developing analytical tools and methodologies to differentiate and quantify natural, engineered and incidental NMs and further to determine the sources of NMs in the environment; 5) assessing the interaction and toxicity of NMs (and mixtures of NMs and trace components carried by NMs) 
to all sectors of the biosphere within the urban environment; 6) exploring ways to mitigate and/or eliminate the most adverse bio-disrupting aspects of ENM and INM interactions within the urban environment; and 7) re-investigating the geochemical cycle of, e.g., metals, taking into account the significant occurrence of these metals in the form of $\mathrm{NM}$ components in the urban environment.

\section{List of abbreviations}

ENMs: Engineered nanomaterials

INMs: incidental nanomaterials

NMs: nanomaterials, encompassing both ENMs and incidental nanomaterials

WWTPs: wastewater treatment plants

PM: particulate matter

UFP: ultrafine particles

$\mathrm{PM}_{2.5}$ : particulate matter $<2.5 \mu \mathrm{m}$

$\mathrm{PM}_{10}$ : particulate matter $<10 \mu \mathrm{m}$

SPM: suspended particulate matter

PGE: platinum group element

VOCs: volatile organic matter

SVOCs: semi-volatile organic matter

IARC: International Agency for Research on Cancer

EM: electron microscopy

TEM: transmission electron microscopy

STEM: scanning transmission electron microscopy

SEM: scanning electron microscopy,

EDX: energy-dispersive X-ray spectroscopy

SAED: selected area electron diffraction

WHO: World Health Organization

HD: high density

GS: green space 


\section{Acknowledgments}

Grants from the South Carolina Sea Grant Consortium; from the National Science Foundation (NSF, 1437307, 1553909) and the Environmental Protection Agency (EPA) in the United States under NSF Cooperative Agreement EF-0830093, entitled Center for the Environmental Implications of Nanotechnology (CEINT); and the National Natural Science Foundation of China (41130525, 41522111 and 41271473) provided major financial support for this study. Additional support was provided by the Fundamental Research Funds for the Central Universities, via the Open Foundation of East China Normal University. The authors thank Stephen McCartney and Christopher Winkler in the Nanoscale Characterization and Fabrication Laboratory at Virginia Tech for assistance with electron microscopes used in this study, and finally the NSF-funded National Center for Earth and Environmental Nanotechnology Infrastructure at Virginia Tech (1542100).

\section{Supporting Information Available}

More detailed information on the sampling sites and the sample collection procedures, along with supplementary graphs and figures, is available in the supporting information section 


\section{References}

Abdul-Razzaq W, Gautam M. Discovery of magnetite in the exhausted material from a diesel engine. Appl Phys Lett 2001; 78: 2018-2019.

Adachi K. Characterization of atmospheric dry deposition particulates in Kobe, Japan. Chemosphere 2006; 64: 1311-1317.

Adachi K, Tainosho Y. Characterization of heavy metal particles embedded in tire dust. Environ Int 2004; 30: 1009-1017.

Al-Kattan A, Wichser A, Vonbank R, Brunner S, Ulrich A, Zuin S, Arroyo Y, Golanski L, Nowack B. Characterization of materials released into water from paint containing nano-SiO ${ }_{2}$. Chemosphere 2015; 119: 1314-1321.

Al-Kattan A, Wichser A, Vonbank R, Brunner S, Ulrich A, Zuin S, Nowack B. Release of $\mathrm{TiO}_{2}$ from paints containing pigment- $\mathrm{TiO}_{2}$ or nano- $\mathrm{TiO}_{2}$ by weathering. Environ Sci : Processes Impacts 2013; 15: 21862193.

Ancelet T, Davy PK, Trompetter WJ, Markwitz A, Weatherburn DC. Carbonaceous aerosols in an urban tunnel. Atmos Environ 2011; 45: 4463-4469.

Ancion PY, Lear G, Lewis GD. Three common metal contaminants of urban runoff $(\mathrm{Zn}, \mathrm{Cu} \& \mathrm{~Pb})$ accumulate in freshwater biofilm and modify embedded bacterial communities. Environ Pollut 2010; 158: $2738-2745$.

Baalousha M, Arkill KP, Romer I, Palmer RE, Lead JR. Transformations of citrate and tween coated silver nanoparticles reacted with $\mathrm{Na}_{2} \mathrm{~S}$. Sci Tot Environ 2015a; 502: 344-353.

Baalousha M, How W, Valsami-Jones E, Lead JR. Overview of environmental nanoscience. In: ValsamiJones E, Lead JR, editors. Nanoscience and the Environment. Elsvier, 2014.

Baalousha M, Lead JR. Nanoparticle dispersity in toxicology. Nat Nanotechnol 2013; 8: 308-309.

Baalousha M, Sikder M, Prasad A, Lead J, Merrifield R, Chandler GT. The concentration-dependent behavior of nanoparticles. Env Chem. 2015; 13: 1-3..

Balasubramanian R, Victor T, Chun N. Chemical and Statistical Analysis of Precipitation in Singapore. Water, Air, \& Soil Pollution 2001; 130: 451-456.

Barbante C, Veysseyre A, Ferrari C, Van De Velde K, Morel C, Capodaglio G, Cescon P, Scarponi G, Boutron C. Greenland Snow Evidence of Large Scale Atmospheric Contamination for Platinum, Palladium, and Rhodium. Environ Sci Technol 2001; 35: 835-839.

Barefoot RR. Distribution and speciation of platinum group elements in environmental matrices. Trends Anal Chem 1999; 18: 702-707. 
Barrett JES, Taylor KG, Hudson-Edwards KA, Charnock JM. Solid-Phase Speciation of Pb in Urban Road Dust Sediment: A XANES and EXAFS Study. Environ Sci Technol 2010; 44: 2940-2946.

Barton LE, Auffan M, Olivi L, Bottero JY, Wiesner MR. Heteroaggregation, transformation and fate of $\mathrm{CeO}_{2}$ nanoparticles in wastewater treatment. Environ Pollut 2015; 203: 122-129.

Beelen R, Stafoggia M, Raaschou-Nielsen O, Andersen ZJ, Xun WW, Katsouyanni K, Dimakopoulou K, Brunekreef B, Weinmayr G, Hoffmann B, Wolf K, Samoli E, Houthuijs D, Nieuwenhuijsen M, Oudin A, Forsberg B, Olsson D, Salomaa V, Lanki T, Yli-Tuomi T, Oftedal B, Aamodt G, Nafstad P, De Faire U, Pedersen NL, Östenson CG, Fratiglioni L, Penell J, Korek M, Pyko A, Eriksen KT, Tjønneland A, Becker T, Eeftens $M$, Bots $M$, Meliefste K, Wang M, Bueno-de-Mesquita B, Sugiri D, Krämer U, Heinrich J, de Hoogh K, Key T, Peters A, Cyrys J, Concin H, Nagel G, Ineichen A, Schaffner E, Probst-Hensch N, Dratva J, DucretStich R, Vilier A, Clavel-Chapelon F, Stempfelet M, Grioni S, Krogh V, Tsai MY, Marcon A, Ricceri F, Sacerdote C, Galassi C, Migliore E, Ranzi A, Cesaroni G, Badaloni C, Forastiere F, Tamayo I, Amiano P, Dorronsoro M, Katsoulis M, Trichopoulou A, Vineis P, Hoek G. Long-term Exposure to Air Pollution and Cardiovascular Mortality: An Analysis of 22 European Cohorts. Epidemiology 2014; 25.

Beeston MP, van Elteren JT, Selih VS, Fairhurst R. Characterization of artificially generated PbS aerosols and their use within a respiratory bioaccessibility test. Analyst 2010; 135: 351-357.

Benn TM, Westerhoff P. Nanoparticle Silver Released into Water from Commercially Available Sock Fabrics. Environ Sci Technol 2008; 42: 4133-4139.

Betzer PR, Carder KL, Duce RA, Merrill JT, Tindale NW, Uematsu M, Costello DK, Young RW, Feely RA, Breland JA, Bernstein RE, Greco AM. Long-range transport of giant mineral aerosol particles. Nature 1988; 336: 568-571.

Bosi F, Hålenius U, Kogby H. Crystal chemistry of the magnetite-ulvöspinel series. American Mineralogist 2009; 94: 181-189.

Bowles, J. F. W. and Gize, A. P. A preliminary study of the release of platinum and palladium from metallic particles in the surface environment by organic acids: relevance to weathering of particles from vehicle exhaust catalysts. Mineralogical Magazine 69[5], 687-693. 2005.

Brar SK, Verma M, Tyagi RD, Surampalli RY. Engineered nanoparticles in wastewater and wastewater sludge - Evidence and impacts. Waste Manag 2010; 30: 504-520.

Buseck PR, Adachi K. Nanoparticles in the Atmosphere. Elements 2008; 4: 389-394.

Capannelli G, Castello E, Comite A, Costa C, Mamolini G. Electron microscopy characterization of airborne micro- and nanoparticulate matter. J Electr Microsc 2011.

Choi J, Batchelor B. Nitrate reduction by fluoride green rust modified with copper. Chemosphere 2008; 70: 1108-1116.

Christian P, Von der Kammer F, Baalousha M, Hofmann Th. Nanoparticles: Structure, Properties, Preparation and Behaviour in Environmental Media. Environ Toxicol Chem 2008; 17: 326-343. 
Christiansen BC, Balic-Zunic T, Dideriksen K, Stipp SLS. Identification of green rust in groundwater. Environ Sci Technol 2009; 43: 3436-3441.

Cinti D, Angelone M, Masi U, Cremisini C. Platinum levels in natural and urban soils from Rome and Latium (Italy): significance for pollution by automobile catalytic converter. Sci Tot Environ 2002; 293: 4757.

Clarke AG, Robertson LA, Hamilton RS, Gorbunov B. A Lagrangian model of the evolution of the particulate size distribution of vehicular emissions. Sci Tot Environ 2004; 334-335: 197-206.

Cosden JM, Schijf J, Byrne RH. Fractionation of Platinum Group Elements in Aqueous Systems: Comparative Kinetics of Palladium and Platinum Removal from Seawater by Ulva lactuca L. Environ Sci Technol 2003; 37: 555-560.

Councell TB, Duckenfield KU, Landa ER, Callender E. Tire-Wear Particles as a Source of Zinc to the Environment. Environ Sci Technol 2004; 38: 4206-4214.

Davis AP, Shokouhian M, Ni S. Loading estimates of lead, copper, cadmium, and zinc in urban runoff from specific sources. Chemosphere 2001; 44: 997-1009.

Doolette C, McLaughlin M, Kirby J, Batstone D, Harris H, Ge H, Cornelis G. Transformation of PVP coated silver nanoparticles in a simulated wastewater treatment process and the effect on microbial communities. Chem Cent J 2013; 7: 1-18.

Duan J, Tan J, Wang S, Hao J, Chai F. Size distributions and sources of elements in particulate matter at curbside, urban and rural sites in Beijing. J Environ Sci 2012; 24: 87-94.

Duester L, Burkhardt M, Gutleb A, Kaegi R, Macken A, Meermann Br, von der Kammer F. Towards a comprehensive and realistic risk evaluation of engineered nanomaterials in the urban water system. Green Environ Chem 2014; 2: 39.

Dylla $\mathrm{H}$, Hassan M. Characterization of nanoparticles released during construction of photocatalytic pavements using engineered nanoparticles. J Nanopart Res 2012; 14: 1-15.

Elzinga EJ, Gao Y, Fitts JP, Tappero R. Iron speciation in urban dust. Atmos Environ 2011; 45: 4528-4532.

Feng X, Dang Z, Huang W, Shao L, Li W. Microscopic morphology and size distribution of particles in PM2.5 of Guangzhou City. J Atmos Chem 2009; 64: 37-51.

Fergusson JE, Kim ND. Trace elements in street and house dusts: sources and speciation. Sci Tot Environ 1991; 100: 125-150.

Fu H, Zhang M, Li W, Chen J, Wang L, Quan X, Wang W. Morphology, composition and mixing state of individual carbonaceous aerosol in urban Shanghai. Atmos Chem Phys 2012; 12: 693-707.

Fukuzaki N, Yanaka T, Urushiyama Y. Effects of studded tires on roadside airborne dust pollution in Niigata, Japan. Atm Environ 1986; 20: 377-386. 
Granat, L., 1972, On the relation between $\mathrm{pH}$ and the chemical composition in atmospheric precipitation: Tellus, v. 24 , no. 6 , p. 550-560.

George C, Ammann M, D'Anna B, onaldson DJ, izkorodov SA. Heterogeneous Photochemistry in the Atmosphere. Chem Rev 2015; 115: 4218-4258.

Gidhagen L, Johansson C, Omstedt G, Langner J, Olivares G. Model Simulations of NOx and Ultrafine Particles Close to a Swedish Highway. Environ Sci Technol 2004; 38: 6730-6740.

Global Industry Analysts Coatings. Global strategic business report. 2012. San Jose, Ca, USA. Global Industry Analysts.

Goel A, Kumar P. Characterisation of nanoparticle emissions and exposure at traffic intersections through fast-response mobile and sequential measurements. Atmos Environ 2015; 107: 374-390.

Gómez B, Gómez M, Sanchez JL, Fernández R, Palacios MA. Platinum and rhodium distribution in airborne particulate matter and road dust. Sci Tot Environ 2001; 269: 131-144.

Gondikas AP, von der Kammer F, Reed RB, Wagner S, Ranville JF, Hofmann T. Release of TiO2 nanoparticles from sunscreens into surface waters: a one-year survey at the Old Danube recreational lake. Environ Sci Technol 2014; 48: 5415-5422.

Gottschalk F, Sonderer T, Scholz RW, Nowack B. Modeled Environmental Concentrations of Engineered Nanomaterials (TiO2, ZnO, Ag, CNT, Fullerenes) for Different Regions. Environ Sci Technol 2009; 43: 9216-9222.

Gottschalk F, Sun T, Nowack B. Environmental concentrations of engineered nanomaterials: Review of modeling and analytical studies. Environmental Pollution 2013; 181: 287-300.

Grassian VH. When Size Really Matters: Size-Dependent Properties and Surface Chemistry of Metal and Metal Oxide Nanoparticles in Gas and Liquid Phase Environments. J Phys Chem C 2008; 112: 1830318313.

Grobéty B, Gieré R, Dietze V, Stille P. Airborne Particles in the Urban Environment. Elements 2010; 6: 229-234.

Gunawardena J, Egodawatta P, Ayoko GA, Goonetilleke A. Atmospheric deposition as a source of heavy metals in urban stormwater. Atm Environ 2013; 68: 235-242.

Han L, Cheng S, Zhuang G, Ning H, Wang H, Wei W, Zhao X. The changes and long-range transport of $\mathrm{PM}_{2.5}$ in Beijing in the past decade. Atm Environ 2015; 110: 186-195.

Hansen HCB. Environmental chemistry of iron (II)-iron (III) LDHs (green rusts). Layered double hydroxides: present and future. Nova Science Publishers Huntington, NY, 2001, pp. 469-493.

Healy RM, O'Connor IP, Hellebust S, Allanic A, Sodeau JR, Wenger JC. Characterisation of single particles from in-port ship emissions. Atmos Environ 2009; 43: 6408-6414. 
HEI Review Panel on Ultrafine Particles. Understanding the Health Effects of Ambient Ultrafine Particles. HEI Perspectives 3. 2013. Boston, MA, Health Effects Institute.

Hemphill CP, Ruby MV, Beck BD, Davis A, Bergstrom PD. The Bioavailability of Lead in Mining Wastes: Physical/Chemical Considerations. Chem Speciation Bioavailability 1991; 3: 135-148.

Hischier, R., and T. Walser, 2012, Life cycle assessment of engineered nanomaterials: State of the art and strategies to overcome existing gaps: Sci.Tot.Environ., v. 425, p. 271-282.

Hochella MF, Aruguete DM, Kim B, Madden AS. Naturally occurring inorganic nanoparticles: general assessment and a global budget for one of Earth's last unexplored major geochemical components. In: Barnard AS, Guo H, editors. Pan Stanford Publishing, Singapore, 2012, pp. 1-42.

Hochella MF, Moore JN, Putnis C, Putnis A, Kasama T, Eberl DD. Direct observation of toxic metalmineral association from a massive acid mine drainage system: Implications for metal transport and bioavailability. Geochim Cosmochim Acta 2005; 69: 1651-1663.

Jartun M, Ottesen RT. Urban geochemistry. Frontiers in Geochemistry: Contribution of Geochemistry to the Study of the Earth 2011; 221-237.

Jensen KH, Rauch S, Morrison GM, Lindberg P. Platinum Group Elements in the Feathers of Raptors and Their Prey. Arch Environ Contam Toxicol 2002; 42: 338-347.

Johnson CA, Freyer G, Fabisch M, Caraballo MA, Küsel K, Hochella MF. Observations and assessment of iron oxide and green rust nanoparticles in metal-polluted mine drainage within a steep redox gradient. Environ Chem 2014; 11: 377-391.

Johnson CA, Murayama M, Küsel K, Hochella MF. Polycrystallinity of green rust minerals and their synthetic analogs: Implications for particle formation and reactivity in complex systems. Am Mineral 2015; 100: 2091-2105.

Kaegi R, Ulrich A, Sinnet B, Vonbank R, Wichser A, Zuleeg S, Simmler H, Brunner S, Vonmont H, Burkhardt $\mathrm{M}$, Boller $\mathrm{M}$. Synthetic $\mathrm{TiO}_{2}$ nanoparticle emission from exterior facades into the aquatic environment. Environ Pollut 2008; 156: 233-239.

Kaegi R, Sinnet B, Zuleeg S, Hagendorfer H, Mueller E, Vonbank R, Boller M, Burkhardt M. Release of silver nanoparticles from outdoor facades. Environ Pollut 2010; 158: 2900-2905.

Kaegi R, Voegelin A, Ort C, Sinnet B, Thalmann B, Krismer J, Hagendorfer H, Elumelu M, Mueller E. Fate and transformation of silver nanoparticles in urban wastewater systems. Wat Res 2013; 47: 3866-3877.

Kaegi R, Voegelin A, Sinnet B, Zuleeg S, Hagendorfer H, Burkhardt M, Siegrist H. Behavior of Metallic Silver Nanoparticles in a Pilot Wastewater Treatment Plant. Environ Sci Technol 2011; 45: 3902-3908.

Kent RD, Oser JG, Vikesland PJ. Controlled Evaluation of Silver Nanoparticle Sulfidation in a Full-Scale Wastewater Treatment Plant. Environ Sci Technol 2014; 48: 8564-8572.

Kim, B.; Hochella, M. F. Analytical Transmission Electron Microscopy and Scanning Transmission Electron Microscopy Techniques for the Characterization of Nanomaterial Composition, Phase and Crystallinity. 
In Frontiers of Nanoscience. Characterization of Nanomaterials in Complex Environmental and Biological Media; Mohammed Baalousha and Jamie, Ed.; Elsevier: 2015.

Kim B, Levard Cm, Murayama M, Brown GE, Hochella MF. Integrated Approaches of X-Ray Absorption Spectroscopic and Electron Microscopic Techniques on Zinc Speciation and Characterization in a Final Sewage Sludge Product. J Environ Quality 2014; 43: 908-916.

Kim B, Park CS, Murayama M, Hochella MF. Discovery and Characterization of Silver Sulfide Nanoparticles in Final Sewage Sludge Products. Environ Sci Technol 2010; 44: 7509-7514.

Kiser MA, Westerhof P, Benn T, Wang Y, Perez-Rivera J, Hristovski K. Titanium Nanomaterial Removal and Release from Wastewater Treatment Plants. Environ Sci Technol 2009; 43: 6757-6763.

Klaine SJ, Alvarez PJJ, Batley GE, Fernandes TF, Handy RD, Lyon DY, Mahendra S, McLaughlin MJ, Lead JL. Nanomaterials in the environment : behaviour, fate, bioavailability and effects. Environ Toxicol Chem 2008; 27: 1825-1851.

Kolodziejczak-Radzimska A, Jesionowski T. Zinc oxide - from synthesis to application: a review. Materials 2014; 7: 2833-2881.

Kreidenweis SM, Tyndall GS, Barth MC, Dentener F, Lelieveld J, Mozurkewich M. Aerosols and clouds, in Atmospheric Chemistry and Global Change. In: Brasseur GP, Orlando JJ, yndall GS, editors. Atmospheric Chemistry and Global Change. Oxford University Press, New York, 1999.

Kroll JH, Seinfeld JH. Chemistry of secondary organic aerosol: Formation and evolution of low-volatility organics in the atmosphere. Atm Environ 2008; 42: 3593-3624.

Kukutschová J, Moravec P, Tomásek V, Matejka V, Smolik J, Schwarz J, Seidlerova J, Safarova K, Filip P. On airborne nano/micro-sized wear particles released from low-metallic automotive brakes. Environ Pollut 2011; 159: 998-1006.

Kumar P, Gurjar BR, Nagpure AS, Harrison RM. Preliminary Estimates of Nanoparticle Number Emissions from Road Vehicles in Megacity Delhi and Associated Health Impacts. Environ Sci Technol 2011; 45: 5514-5521.

Kumar P, Morawska L, Birmili W, Paasonen P, Hu M, Kulmala M, Harrison RM, Norford L, Britter R. Ultrafine particles in cities. Environ Int 2014; 66: 1-10.

Kumar P, Robins A, Vardoulakis S, Britter R. A review of the characteristics of nanoparticles in the urban atmosphere and the prospects for developing regulatory controls. Atmos Environ 2010; 44: 5035-5052.

Künniger T, Gerecke AC, Ulrich A, Huch A, Vonbank R, Heeb M, Wichser A, Haag R, Kunz P, Faller M. Release and environmental impact of silver nanoparticles and conventional organic biocides from coated wooden facades. Environ Pollut 2014; 184: 464-471.

Lee J, Mahendra S, Alvarez PJ. Nanomaterials in the construction industry: a review of their applications and environmental health and safety considerations. ACS Nano 2010; 4: 3580-3590. 
Lelieveld J, Evans JS, Fnais M, Giannadaki D, Pozzer A. The contribution of outdoor air pollution sources to premature mortality on a global scale. Nature 2015; 525: 367-371.

Levard C, Hotze EM, Lowry GV, Brown GE. Environmental Transformations of Silver Nanoparticles: Impact on Stability and Toxicity. Environ Sci Technol 2012; 46: 6900-6914.

Levard C, Reinsch BC, Michel FM, Oumahi C, Lowry GV, Brown GE. Sulfidation Processes of PVP-Coated Silver Nanoparticles in Aqueous Solution: Impact on Dissolution Rate. Environ Sci Technol 2011; 45: 5260-5266.

Li WJ, Liu CX, Wang L. Non-lead gasoline and trend of lead pollution in air. Urban Environ Urban Ecol 2000; 20: 61-62.

Lowry GV, Gregory KB, Apte SC, Lead JR. Transformations of Nanomaterials in the Environment. Environ Sci Technol 2012; 46: 6893-6899.

Lyons WB, Harmon RS. Why urban geochemistry? Elements 2012; 8: 417-422.

Ma R, Levard C, Judy JD, Unrine JM, Durenkamp M, Martin B, Jefferson B, Lowry GV. Fate of zinc oxide and silver nanoparticles in a pilot wastewater treatment plant and in processed biosolids. Environ Sci Technol 2014a; 48: 104-112.

Ma R, Levard Cm, Michel FM, Brown GE, Lowry GV. Sulfidation Mechanism for Zinc Oxide Nanoparticles and the Effect of Sulfidation on Their Solubility. Environ Sci Technol 2013; 47: 2527-2534.

Ma R, Stegemeier J, Levard C, Dale J, Noack CW, Yang T, Brown G, Lowry G. Sulfidation of copper oxide nanoparticles and properties of resulting copper sulfide. Environ Sci Nano 2014b; 1: 347-357.

Madden AS, Hochella J, Luxton TP. Insights for size-dependent reactivity of hematite nanomineral surfaces through $\mathrm{Cu}^{2+}$ sorption. Geochim Cosmochim Acta 2006; 70: 4095-4104.

Mirabedini SM, Jamali SS, Haghayegh M, Sharifi M, Mirabedini AS, Hashemi-Nasab R. Application of mixture experimental design to optimize formulation and performance of thermoplastic road markings. Prog Org Coat 2012; 75: 549-559.

Montano MD, Lowry GV, von der Kammer F, Blue J, Ranville JF. Current status and future direction for examining engineered nanoparticles in natural systems. Environ Chem 2014; 11: 351-366.

Morawska L, Wang H, Ristovski Z, Jayaratne ER, Johnson G, Cheung HC, Ling X, He C. JEM Spotlight: Environmental monitoring of airborne nanoparticles. J Environ Monit 2009; 11: 1758-1773.

Morton-Bermea O, Amador-Muñoz O, Martìnez-Trejo L, Hernández-Álvarez E, Beramendi-Orosco L, García-Arreola ME. Platinum in $\mathrm{PM}_{2.5}$ of the metropolitan area of Mexico City. Environ Geochem Health 2014; 36: 987-994.

Munafò P, Quagliarini E, Goffredo GB, Bondioli F, Licciulli A. Durability of nano-engineered TiO2 selfcleaning treatments on limestone. Constr Build Mater 2014; 65: 218-231. 
Nash DG, Baer T, Johnston MV. Aerosol mass spectrometry: An introductory review. Int J Mass Spectr 2006; 258: 2-12.

Nie W, Ding A, Wang T, Kerminen V M, George C, Xue L, Wang W, Zhang Q, Petäjä T, Qi X. Polluted Dust Promotes New Particle Formation and Growth. Sci. Rep. 2014; 4: 6634-1 - 6634-6.

Oberdörster G. Safety assessment for nanotechnology and nanomedicine: concepts of nanotoxicology. J Int Med 2010; 267: 89-105.

OECD. Nanotechnology and Tyres: Greening Industry and Transport. OECD publishing, http://dx.doi.org/10.1787/9789264209152-en, 2014.

Olabarrieta J, Zorita S, Pena I, Rioja N, Monzón O, Benguria P, Scifo L. Aging of photocatalytic coatings under a water flow: Long run performance and $\mathrm{TiO}_{2}$ nanoparticles release. Appl Catal B Environ 2012; 123-124: 182-192.

Omstedt G, Bringfelt B, Johansson C. A model for vehicle-induced non-tailpipe emissions of particles along Swedish roads. Atmos Environ 2005; 39: 6088-6097.

Pazokifard S, Esfandeh M, Mirabedini SM, Mohseni M, Ranjbar Z. Investigating the role of surface treated titanium dioxide nanoparticles on self-cleaning behavior of an acrylic facade coating. J Coat Technol Res 2013; 10: 175-187.

Peijnenburg WJ, Baalousha M, Chen J, Chaudry Q, von der Kammer F, Kuhlbusch TA, Lead J, Nickel C, Quik JT, Renker M. A review of the properties and processes determining the fate of engineered nanomaterials in the aquatic environment. Crit Rev Environ Sci Technol 2015; 45: 2084-2134.

Piccinno F, Gottschalk F, Seeger S, Nowack B. Industrial production quantities and uses of ten engineered nanomaterials in Europe and the world. J Nanopart Res 2012; 14: 1-11.

Prichard HM, Jackson MT, Sampson J. Dispersal and accumulation of Pt, Pd and Rh derived from a roundabout in Sheffield (UK): From stream to tidal estuary. Sci Tot Environ 2008; 401: 90-99.

Prichard HM, Fisher PC. Identification of Platinum and Palladium Particles Emitted from Vehicles and Dispersed into the Surface Environment. Environ Sci Technol 2012; 46: 3149-3154.

Prospero JM. Long-range transport of mineral dust in the global atmosphere: Impact of African dust on the environment of the southeastern United States. Proc Nat Acad Sci 1999a; 96: 3396-3403.

Prospero JM. Long-term measurements of the transport of African mineral dust to the southeastern United States: Implications for regional air quality. J Geophys Res Atms 1999b; 104: 15917-15927.

Quadros ME, Marr LC. Environmental and Human Health Risks of Aerosolized Silver Nanoparticles. J Air Waste Manag Assoc 2010; 60: 770-781.

Ravindra K, Bencs L, Van Grieken R. Platinum group elements in the environment and their health risk. Sci Tot Environ 2004; 318: 1-43. 
Reinard MS, Adou K, Martini JM, Johnston MV. Source characterization and identification by real-time single particle mass spectrometry. Atmos Environ 2007; 41: 9397-9409.

Renwick WH, Sleezer RO, Buddemeier RW, Smith SV. Small artificial ponds in the United States: impacts on sedimentation and carbon budget. Proceedings of the Eighth Federal Interagency Sedimentation Conference (8thFISC), Reno, NV, USA, 2006, pp. 738-744.

Rogge WF, Hildemann LM, Mazurek MA, Cass GR, Simoneit BRT. Sources of fine organic aerosol. 3. Road dust, tire debris, and organometallic brake lining dust: roads as sources and sinks. Environ Sci Technol 1993; 27: 1892-1904.

Salvador P, Artiñano B, Molero F, Viana M, Pey J, Alastuey A, Querol X. African dust contribution to ambient aerosol levels across central Spain: Characterization of long-range transport episodes of desert dust. Atm Res 2013; 127: 117-129.

Sanderson P, Delgado-Saborit JM, Harrison RM. A review of chemical and physical characterisation of atmospheric metallic nanoparticles. Atm Environ 2014; 94: 353-365.

Sanger DM, Holland AF, Scott GI. Tidal Creek and Salt Marsh Sediments in South Carolina Coastal Estuaries: I. Distribution of Trace Metals. Arch Environ Contam Toxicol 1999; 37: 445-457.

Seinfeld JH, Pandis SN. Atmospheric chemistry and physics: from air pollution to climate change. John Wiley \& Sons, 2012.

Skinner BJ. Unit-cell edges of natural and synthetic sphalerites. American Mineralogist 1961; 46: 13991411.

Smolders E, Degryse F. Fate and Effect of Zinc from Tire Debris in Soil. Environ Sci Technol 2002; 36: 3706-3710.

Sternbeck J, Sjödin Å, Andréasson K. Metal emissions from road traffic and the influence of resuspension results from two tunnel studies. Atm Environ 2002; 36: 4735-4744.

Sutherland R, Pearson G, Ottley C, Ziegler A. Platinum-Group Elements in Urban Fluvial Bed SedimentsHawaii. In: Zereini F, Wiseman CLS, editors. Platinum Metals in the Environment. Springer Berlin Heidelberg, 2015, pp. 163-186.

Thorpe A, Harrison RM. Sources and properties of non-exhaust particulate matter from road traffic: A review. Sci Tot Environ 2008; 400: 270-282.

Tixier G, Lafont M, Grapentine L, Rochfort Q, Marsalek J. Ecological risk assessment of urban stormwater ponds: Literature review and proposal of a new conceptual approach providing ecological quality goals and the associated bioassessment tools. Ecol Indicat 2011; 11: 1497-1506.

U.S.EPA. Risk assessment technical background document for the paint and coatings hazardous waste listing determination. 2011. 401 M Street SW (5307 W), Washington, DC 20460, Office of Solid Waste U.S. Environmental Protection Agency. 
Ugwu OO. Nanotechnology for Sustainable Infrastructure in 21st Century Civil Engineering. J Innov Eng 2013; 1: E2.

Uibel S, Takemura M, Mueller D, Quarcoo D, Klingelhoefer D, Groneberg D. Nanoparticles and cars analysis of potential sources. J Occup Med Toxicol 2012; 7: 1-5.

United Nations. World's population increasingly urban with more than half living in urban areas. 2014.

van Broekhuizen, F. and van Broekhuizen, P. Nano-products in the European Construction Industry. 2009. IVAM UvA BV, Amsterdam, The Netherlands.

van Broekhuizen P, van Broekhuizen F, Cornelissen R, Reijnders L. Use of nanomaterials in the European construction industry and some occupational health aspects thereof. J Nanopart Res 2011; 13: 447-462.

Vance ME, Kuiken T, Vejerano EP, McGinnis SP, HOCHELLA MF, Jr., Rejeski D, Hull MS. Nanotechnology in the real world: Redeveloping the nanomaterial consumer products inventory. Beilstein J Nanotechnol 2015; 6: 1769-1780.

von der Kammer F, Ferguson PL, Holden PA, Masion A, Rogers KR, Klaine SJ, Koelmans AA, Horne N, Unrine JM. Analysis of engineered nanomaterials in complex matrices (environment and biota): General considerations and conceptual case studies. Environ Toxicol Chem 2012; 31: 32-49.

Wang J, Hu Z, Chen Y, Chen Z, Xu S. Contamination characteristics and possible sources of PM10 and PM2.5 in different functional areas of Shanghai, China. Atmos Environ 2013; 68: 221-229.

Wankel SD, Adams MM, Johnston DT, Hansel CM, Joye SB, Girguis PR. Anaerobic methane oxidation in metalliferous hydrothermal sediments: influence on carbon flux and decoupling from sulfate reduction. Environ Microbiol 2012; 14: 2726-2740.

Weir A, Westerhoff P, Fabricius L, Hristovski K, Von Goetz N. Titanium Dioxide Nanoparticles in Food and Personal Care Products. Environ Sci Technol 2012; 46: 2242-2250.

Wells JJ, Wigley F, Foster DJ, Livingston WR, Gibb WH, Williamson J. The nature of mineral matter in a coal and the effects on erosive and abrasive behaviour. Fuel Process Technol 2005; 86: 535-550.

Westerhoff $P$, Song $G$, Hristovski K, Kiser MA. Occurrence and removal of titanium at full scale wastewater treatment plants: implications for $\mathrm{TiO}_{2}$ nanomaterials. J Environ Monit 2011; 13: 1195-1203.

WHO. Health effects of particulate matter. ISBN 978928900001 7. 2013.

Wiek A, Guston D, van der Leeuw S, Selin C, Shapira P. Nanotechnology in the city: sustainability challenges and anticipatory governance. J Urban Technol 2013; 20: 45-62.

Winkless, L. SLIPery and Self-Cleaning: A New Generation of Glass Coatings. Mater.Today.http://www.materialstoday.com/biomaterials/comment/slipery-and-self-cleaning-a-newgeneration-of-glas/ . 8-21-2013.

Wiseman CLS, Zereini F. Airborne particulate matter, platinum group elements and human health: A review of recent evidence. Sci Tot Environ 2009; 407: 2493-2500. 
Wong CSC, Li X, Thornton I. Urban environmental geochemistry of trace metals. Environmental Pollution 2006; 142: 1-16.

Wong Cl, Sharp JM, Hauwert N, Landrum J, White KM. Impact of Urban Development on Physical and Chemical Hydrogeology. Elements 2012; 8: 429-434.

Xia DS, Chen FH, Bloemendal J, Liu XM, Yu Y, Yang LP. Magnetic properties of urban dustfall in Lanzhou, China, and its environmental implications. Atmos Environ 2008; 42: 2198-2207.

Yu R, Lin Q, Leung SF, Fan Z. Nanomaterials and nanostructures for efficient light absorption and photovoltaics. Nano Energy 2012; 1: 57-72.

Zegeye A, Etique M, Carteret C, Ruby C, Schaaf P, Francius G. Origin of the Differential Nanoscale Reactivity of Biologically and Chemically Formed Green Rust Crystals Investigated by Chemical Force Spectroscopy. J Phys Chem C 2014; 118: 5978-5987.

Zhang KM, Wexler AS, Niemeier DA, Zhu YF, Hinds WC, Sioutas C. Evolution of particle number distribution near roadways. Part III: Traffic analysis and on-road size resolved particulate emission factors. Atm Environ 2005; 39: 4155-4166.

Zhang P, Ma Y, Zhang Z, He X, Zhang J, Guo Z, Tai R, Zhao Y, Chai Z. Biotransformation of ceria nanoparticles in cucumber plants. ACS Nano 2012; 6: 9943-9950.

Zhang W, Jiang H, Dong C, Yan Q, Yu L, Yu Y. Magnetic and geochemical characterization of iron pollution in subway dusts in Shanghai, China. Geochem Geophys Geosys 2011; 12: 1-13.

Zuin S, Gaiani M, Ferrari A, Golanski L. Leaching of nanoparticles from experimental water-borne paints under laboratory test conditions. J Nanopart Res 2013; 16: 1-17.

Zuin S, Massari A, Ferrari A, Golanski L. Formulation effects on the release of silica dioxide nanoparticles from paint debris to water. Sci Tot Environ 2014; 476: 298-307.

Yan, C., Y. Yang, J. Zhou, M. Nie, M. Liu, and J. Hochella, 2015, Selected emerging organic contaminants in the Yangtze Estuary, China: A comprehensive treatment of their association with aquatic colloids: J. Hazard. Mater. 2015; 283: 14-23. 


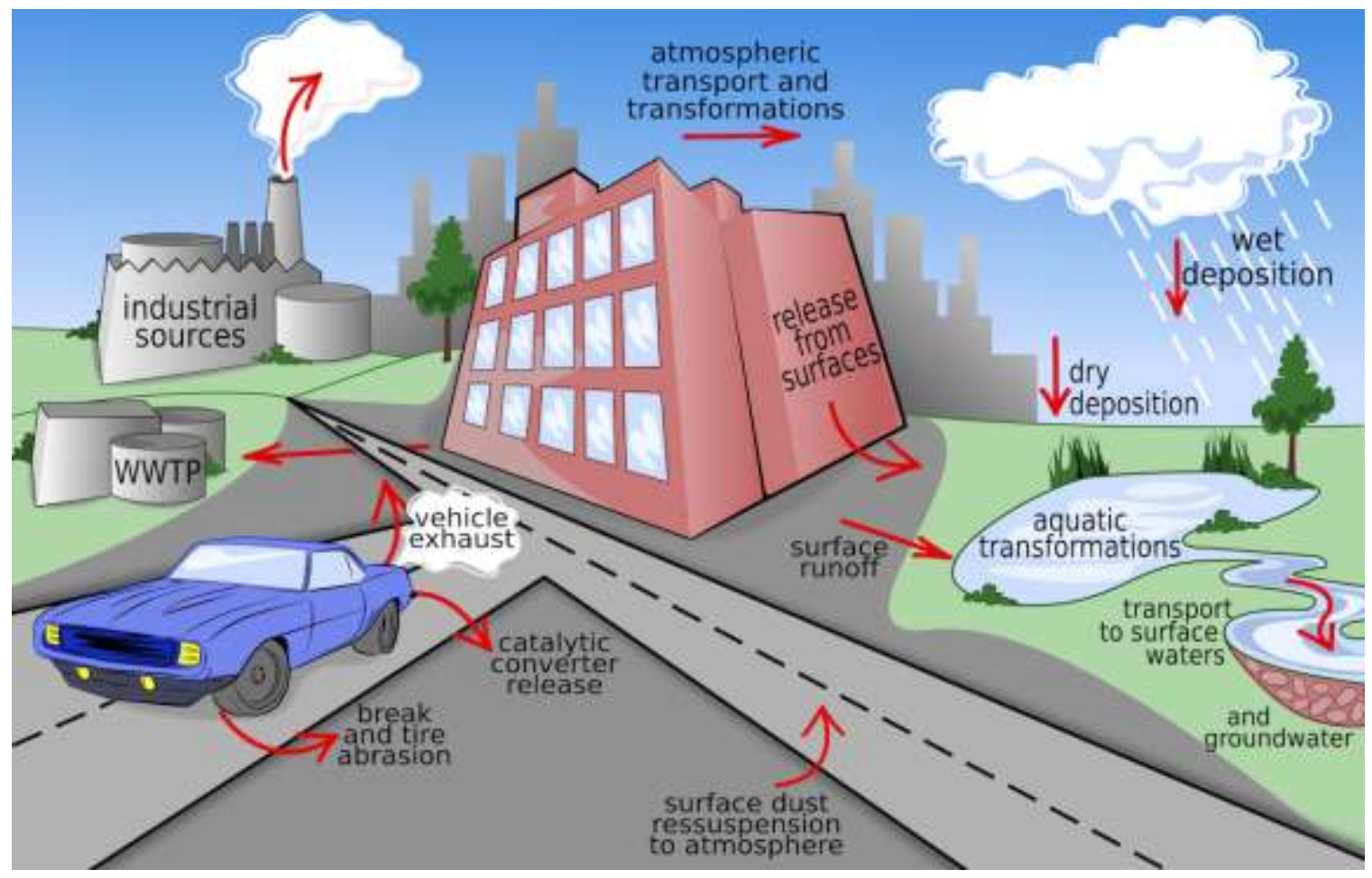

Figure 1. Sources and pathways of outdoor urban nanomaterials in the environment 


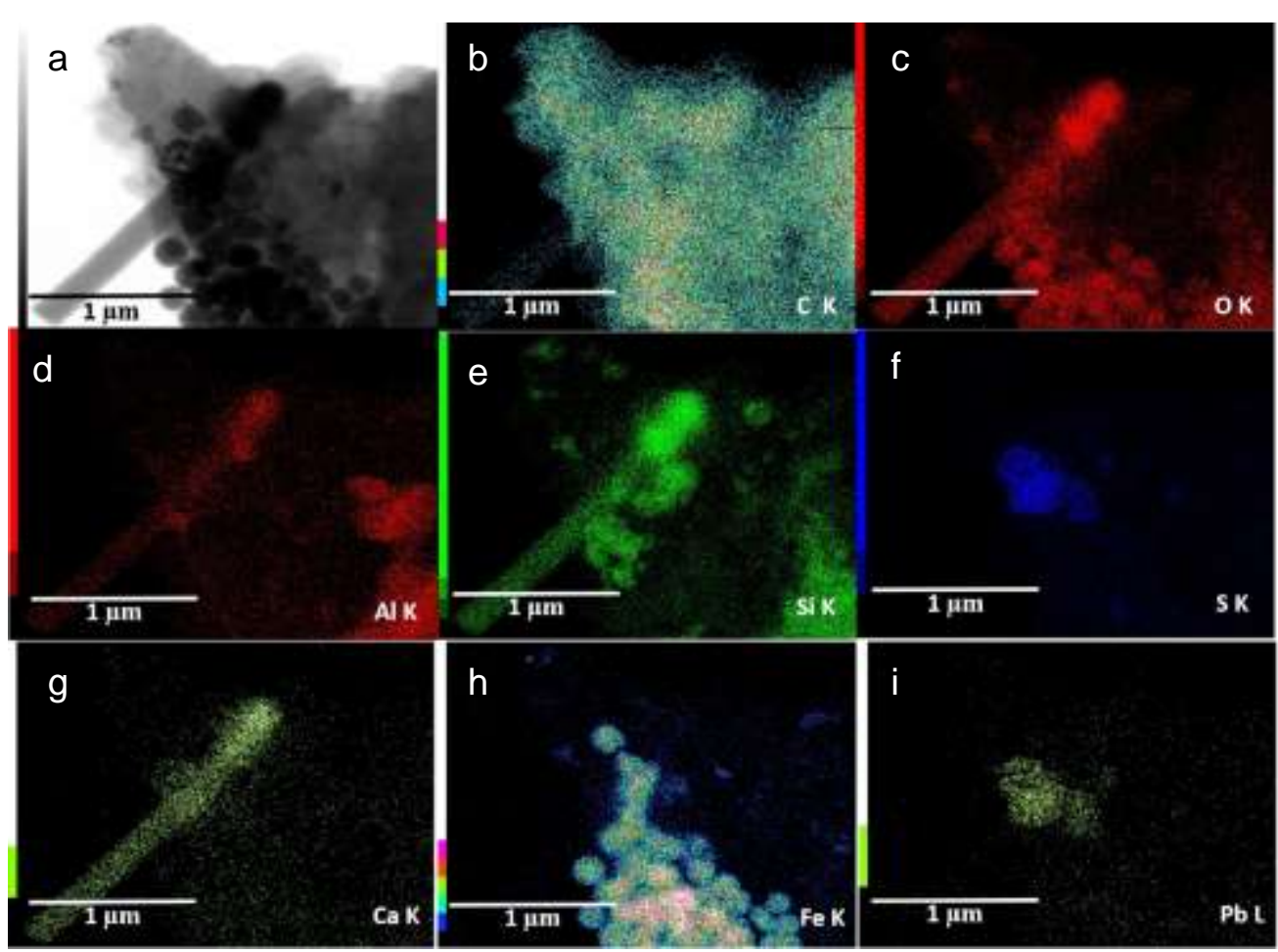

Figure 2. Transmission electron microscopy (TEM) and X-ray energy dispersive spectroscopy (X-EDS) maps of a typical NM aggregate in a carbon matrix found in a $\mathrm{PM}_{2.5}$ sample collected during a hazy day in Shanghai, China: (a) bright field micrograph; and (b-i) elemental maps of $\mathrm{O}, \mathrm{Al}, \mathrm{Si}, \mathrm{S}, \mathrm{Ca}, \mathrm{Fe}$ and $\mathrm{Pb}$, respectively. These analyses indicate the occurrence of iron oxide ( $c$ and $h$ ), galena, $\mathrm{PbS}$ ( $f$ and $i$ ) and $\mathrm{Ca}_{2} \mathrm{SiO}_{4}$ (c, e and g) nanomaterials. Iron oxides were identified as magnetite NMs using their selective area electron diffraction (SAED) patterns (data not shown). 


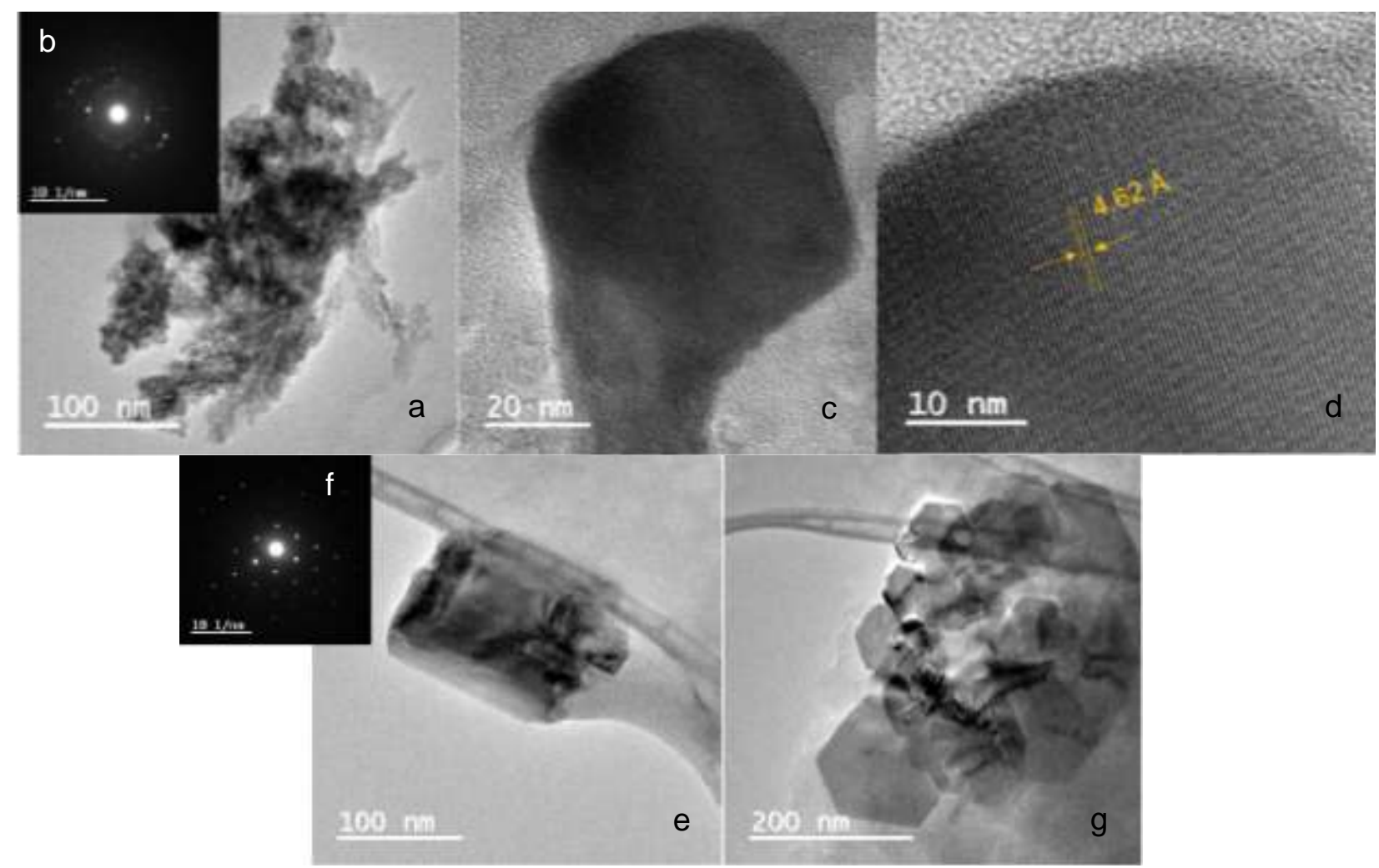

Figure 3. Typical TEM micrographs of iron-based nanomaterials and aggregates detected in different suspended particulate matter (SPM) and sediments from stormwater ponds: (a) hematite; ( $c$ and d) magnetite; (e) goethite; and ( $g$ ) green rust; $b$ and $f$ are selective area electron diffraction (SAED) patterns of particles in panels a and e. 


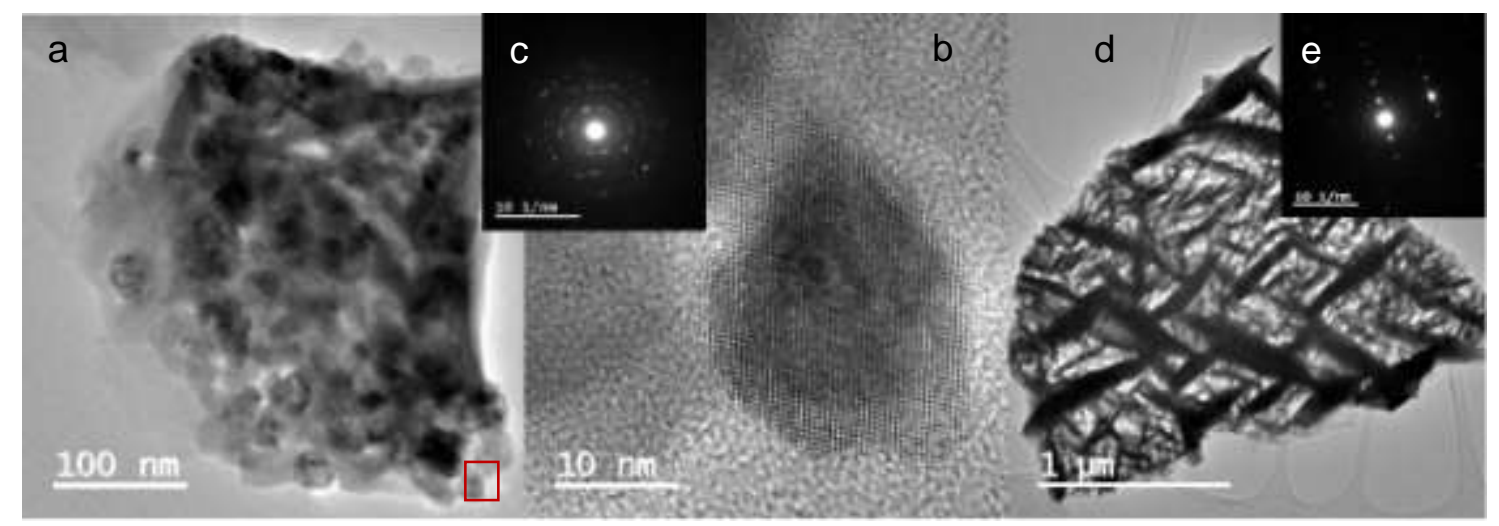

Figure 4. Typical TEM micrographs together with SAED patterns of $\mathrm{TiO}_{2} \mathrm{NMs}$ detected in suspended particulate matter (SPM) in stormwater ponds: (a, b) anatase NM aggregate, (d) rutile NM aggregate, and ( $c$ and e) SAED patterns of particles in panels $b$ and $d$, respectively; (b) is a magnification of a selected area in (a) and shows anatase particle size of $10-20 \mathrm{~nm}$. 


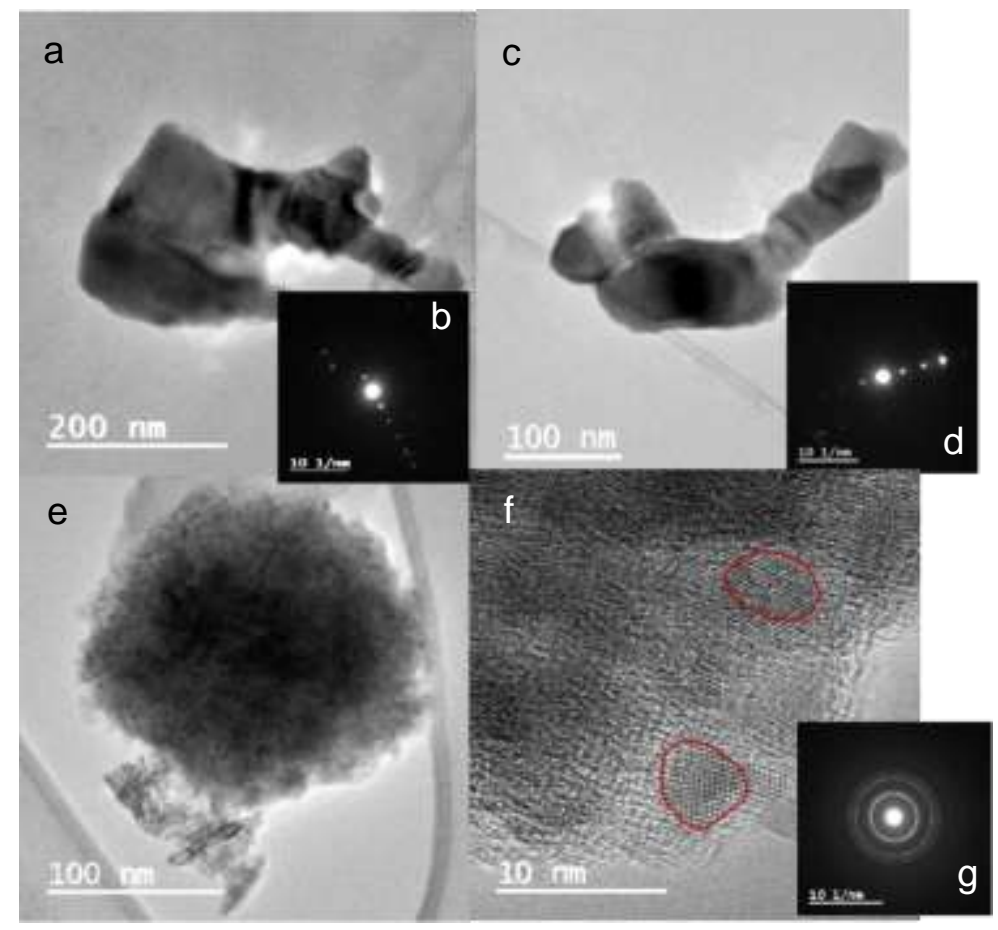

Figure 5. Typical TEM micrographs of zinc rich nanomaterials: (a) ZnO NM aggregates found in the colloidal fraction in a green space stormwater pond (GS_A), (c) ZnO in detected in sediments from a high density stormwater pond (HD-C), (b and d) SAED patterns of particles in panels a and c, (e) ZnS aggregates from sediments collected from a high density stormwater pond (HD-D), (f) magnification of a selected area in e which shows ZnS NMs $<10 \mathrm{~nm}$ in size, and $(\mathrm{g})$ SAED pattern from panel $\mathrm{f}$. 